\title{
Assessment of derelict soil quality: abiotic, biotic and functional approaches
}

\author{
Quentin VINCENT ${ }^{1,2}$, Apolline AUCLERC ${ }^{2}$, Thierry BEGUIRISTAIN ${ }^{1}$ and Corinne \\ LEYVAL 1 . \\ 1. Université de Lorraine, CNRS, Laboratoire Interdisciplinaire des Environnements Continentaux \\ (LIEC), UMR 7360, Vandoeuvre-lès-Nancy, France. \\ ${ }^{2}$. Université de Lorraine, INRA, Laboratoire Sols et Environnement (LSE), UMR 1120, Vandoeuvre- \\ lès-Nancy, France.
}

\begin{abstract}
:
The intensification and subsequent closing down of industrial activities during the last century has left behind large surfaces of derelict lands. Derelict soils have low fertility, can be contaminated, and many of them remain unused. However, with the increasing demand of soil surfaces, they might be considered as a resource, for example for non-food biomass production. The study of their physicochemical properties and of their biodiversity and biological activity may provide indications for their potential re-use. The objective of our study was to investigate the quality of six derelict soils, considering abiotic, biotic, and functional parameters. We studied (i) the soil bacteria, fungi, mesoand macro-fauna and plant communities of six different derelict soils (two from coking plants, one from a settling pond, two constructed ones made from different substrates and remediated soil, and an inert waste storage one), and (ii) their decomposition function based on the decomposer trophic network, enzyme activities, mineralization activity, and organic pollutant degradation.

Biodiversity levels in these soils were high, but all biotic parameters, except the mycorrhizal colonization level, discriminated them. Multivariate analysis showed that biotic parameters co-varied more with fertility proxies than with soil contamination parameters. Similarly, functional parameters significantly co-varied with abiotic parameters. Among functional parameters, macro-decomposer proportion, enzyme activity, average mineralization capacity, and microbial polycyclic aromatic hydrocarbon degraders were useful to discriminate the soils. We assessed their quality by combining abiotic, biotic, and functional parameters: the compost-amended constructed soil displayed the highest quality, while the settling pond soil and the contaminated constructed soil displayed the lowest. Although differences among the soils were highlighted, this study shows that derelict soils may provide a biodiversity ecosystem service and are functional for decomposition.
\end{abstract}

\section{Keywords:}


Derelict soil, Soil quality, Soil biota, Biodiversity, Soil functioning, Technosol.

\section{Introduction}

Soils contribute to basic human needs like food, water, and air supply, and are a major carrier of biodiversity (Keesstra et al., 2016). Soil sustainability and quality are key issues for solving major societal challenges such as food security, water resources, biodiversity (Mol and Keesstra, 2012). Soil quality has been defined by many authors and refers to the "capacity of a living soil to function, within natural or managed ecosystem boundaries, to sustain plant and animal productivity, to maintain or enhance water and air quality, and to support plant and animal health" (Doran, 2002; Karlen et al., 2003). Soil quality is related to ecosystem services such as freshwater purification and regulation (Garrigues et al., 2012), food and fiber production, and the maintenance of global ecosystem functions (Vidal Legaz et al., 2016). To study soil quality, physico-chemical parameters are usually measured, including fertility parameters and contaminant concentrations (Joimel et al., 2016). On the other hand, soil biological parameters are also considered as soil quality indicators (Cluzeau et al., 2012). Estimating soil quality requires to take into account the quantitative and qualitative composition of biological communities as well as the rates, patterns, and relative importance of different ecosystemlevel processes (Gessner and Chauvet, 2002).

The intensification and expansion of human activities has increased the pressure on land resources and led to soil degradation (Levin et al., 2017). Land management, including land restoration, is among the six major global issues of the recently adopted United Nations Sustainable Development Goals (Keesstra et al., 2016). The decline of manufacturing industries because of economic crises in the steel, shipbuilding or metal fabrication industries, as well as the closing down of traditional mining activity, have left behind large numbers of derelict lands around the world (Wong and Bradshaw, 2002; Dangi et al., 2012). For brownfield soils with high contamination levels and high toxicity risks, remediation of pollution is mandatory and controlled by regulatory policies. When contamination is moderate or low, soils remain unmanaged and underused (Cundy et al., 2016). Sometimes called greenfields, wastelands, uncultivated, vacant or abandoned land, these derelict soils can be poor in nutrients (Dickinson, 2003) and/or contaminated (Morel et al., 2005). However, with the estimated increase of the world's population and the increasing need for soil surfaces for plant production, some of these soils might be considered as a resource (Anderson and Minor, 2017), for example for nonfood biomass production (Wilschut et al., 2013; Lord, 2015). The potential of derelict soils to promote non-food biomass production has been studied in willow, miscanthus, reed canarygrass and switchgrass in England (Lord et al., 2008) and in willow, poplar, miscanthus, and kenaf in Europe (Sæbo et al., 2017). In India, marginal and degraded lands have been studied for biomass and biofuel production from Prosopis juliflora and Jatropha curcas (Edrisi and Abhilash, 2016). 
Physico-chemical characteristics of derelict soils may affect their biodiversity (plant, animal and microbial communities) and imply adaptation of biodiversity (Khan et al., 2000, for flora; Cébron et al., 2008, for bacteria; Lucisine et al., 2015, for fauna). However, derelict soils may also be of a heritage interest for biodiversity reserves, e.g. in wastelands (Bonthoux et al., 2014). For instance, wastelands and urban soils in different countries have been reported to harbour a rich biodiversity, for example of flora in Atlantic Canada (Robinson and Lundholm, 2012), of Collembola in France (Joimel et al., 2017), of Coleoptera (Eyre et al., 2003), carabid beetles (Small et al., 2006) and mycorrhizae (Gange and Brown, 2002) in the United Kindom. Similarly, post-mining sites have been reported to harbour a high biodiversity of Collembola, earthworms and other macrofauna taxa (Dunger and Voigtländer, 2009; Frouz et al., 2013). Soil biodiversity is also influenced by the complex interactions among the different biotic components (micro-organisms, meso and macro-fauna and plants) (Wardle et al., 2004; Wardle, 2006), which play an important role in ecosystem functioning (Bardgett and Wardle, 2010; Morriën et al., 2016).

Soil biodiversity and biological activity studies can be relevant to assess soil and whole ecosystem functioning because organisms influence key ecosystem processes such as primary production (Van Der Heijden et al., 2008), decomposition and nutrient cycling (Hafeez et al., 2012), soil aeration (Frouz et al., 2007), water storage (Lavelle et al., 2006), and also organic pollutant degradation (Peng et al., 2008) or protection against metal toxicity (Leyval and Joner, 2001; Amir et al., 2014). For instance, soil biota contributes to the degradation and removal of soil contaminants through natural attenuation after ecosystem disturbances in brownfields (Mulligan and Yong, 2004). Organic matter decomposition is one of the most critical ecosystem processes for nutrient recycling between the aboveground and belowground subsystems (Norris et al., 2013), it is directly performed by several components of living organisms (micro-organisms are decomposers, and several invertebrates such as Diplopoda, Collembola, earthworms are detritivores). When the belowground subsystem is not functional, plant growth can be totally inhibited (Wong and Bradshaw, 2003). Several studies have addressed plant growth on derelict soils (Gardiner et al., 2013; Wilschut et al., 2013; Lord, 2015; Anderson and Minor, 2017) as an indicator of their quality.

Most of the studies dealing with derelict soils considered either their fertility parameters, or their biodiversity, but did not take into account soil biodiversity and functions in interaction with abiotic factors. However, according to an emerging concept of multiple uses of soils (Varallyay, 2000; Wagg et al., 2014), assessing soil quality should not be limited to studying productivity parameters, but should also include broader abiotic, biotic and functional parameters. The originality of our study was to investigate physico-chemical properties, biodiversity and biological activity to provide indications for a potential re-use of derelict soils. The objective of this study was therefore to investigate the quality of several derelict soils, based on an integrated approach addressing abiotic, biotic, and functional parameters and their interactions. To do so, six different derelict soils were chosen and 
sampled: two from coking plant sites, one from a settling pond, two constructed ones and an inert waste storage one. In order to characterize them, we studied a) abiotic parameters, including fertility parameters and contaminant concentrations; b) biotic parameters based on the density and taxonomical diversity of almost all the components of the soil biota: bacteria, fungi (mycorrhizal and nonmycorrhizal), the meso- and macro-fauna, and the plant communities; c) functional parameters: decomposition function through the decomposer trophic network, microbial carbon mineralization and organic pollutant degradation. Finally, to characterize the interactions between the different approaches, we used co-inertia analyses to discriminate the soils according to abiotic, biotic, and functional parameters.

\section{Materials and methods}

Six derelict soils were studied: two from former coking plant sites, two from experimental constructed fields, one from a settling pond site and one from an inert waste storage facility site. The characterization of these soils included abiotic, biotic, and functional parameters. The abiotic parameters were fertility parameters and pollutant concentrations. The biotic parameters were microorganism, fauna and flora density (measured from density, biomass or frequency) and diversity (measured from taxon richness or ribotype number). Lastly, we analysed decomposition activity (meso- and macro-decomposers, enzyme and mineralization activities) as a functional parameter, and quantified polycyclic aromatic hydrocarbon (PAH)-degrading bacteria.

\subsection{Study sites of derelict soils}

Six derelict soils were studied (Table 1) in the Lorraine region (north-eastern France) (Fig. 1) in April 2015. The climate in this region is continental, with mean annual temperatures ranging between 1.4 and $18.5^{\circ} \mathrm{C}$, and annual rainfall around $750 \mathrm{~mm}$. In April 2015, the average temperature was $10.4^{\circ} \mathrm{C}$ (with a minimum of 4.4 and maximum of $16.4^{\circ} \mathrm{C}$ ) and rainfall was $51.2 \mathrm{~mm}$ with a daily minimum of 0 and maximum of $13.4 \mathrm{~mm}$. The sites are located in a former industrial region, that included many coking plant sites and other steel factories.

Soil A was a Spolic Garbic Technosol (IUSS Working Group WRB, 2014) (Table 1). It was an experimental constructed soil (1.13 ha), set up on the site of a former coking plant in 2007 (Sere et al., 2008). It was composed of an 0.3-m bottom layer made of paper mill waste, an 0.6-m layer of thermaldesorption-treated PAH-contaminated soil, and then an $0.15-\mathrm{m}$ topsoil layer made of green-waste compost. It was planted with a mixture of grasses (30\% Lolium perenne var. Tove, $40 \%$ Festuca arundinacea, var. Fuego, 30\% Dactylis glomerata, var. Amba). At the time of sampling, soil moisture was $25 \pm 1 \%(\mathrm{w} / \mathrm{w})$. Soil B was a Skeletic Technosol. It was a non-hazardous waste landfill (0.7 ha), built in 2011; it was made of ground construction and demolition waste. This landfill formed a 7-m high mound, spontaneously colonized by herbaceous plants. The soil moisture was $11 \pm 3 \%(\mathrm{w} / \mathrm{w})$. 
Soils C and E were Spolic Technosols in former coking plant sites closed in 1980 and 1975 respectively. They differed in pollutant concentrations (Table 1), but were both colonized by herbaceous plants. The soil moisture levels were $17 \pm 2 \%$ and $15 \pm 3 \%(\mathrm{w} / \mathrm{w})$ respectively. Soil $\mathrm{D}$ was a Spolic Technosol from a settling pond site filled with steel sludge until 1981 and covered with herbaceous plants. The soil moisture was $17 \pm 1 \%$ (w/w). Lastly, soil F, a Spolic Technosol was an experimental 0.09-ha constructed soil and set up in 2013. It was composed of an 0-0.5-m topsoil layer made of biopile-treated PAH-contaminated soil mixed with heavy metal-contaminated sludge. It was planted with poplar trees (Populus trichocarpa $\times$ P.maximowiczii). Its moisture was $15 \pm 3 \%(\mathrm{w} / \mathrm{w})$.

\subsection{Sampling method}

Five samples were taken from each soil (except soil $\mathrm{F}$ where one sample was missing), along a 20-m transect with 5-m distance between each sample, in accordance with the Tropical Soil Biology and Fertility (TSBF) method (Anderson and Ingram 1993). Thus, 29 samples were collected in total between 8 and 29 April 2015. The TSBF method is designed for sampling soil macrofauna. We extrapolated the method so as to analyse the soil, plant, mesofauna, macrofauna and microflora from our sampling sites. For each sampling point (Fig. 2$)$, a $1 \times 1 \mathrm{~m}$ frame $\left(\mathrm{n}^{\circ} 1\right)$ was first used to characterise plant herbaceous richness (Robinson and Lundholm, 2012). Inside that first frame, another $0.5 \times 0.5 \mathrm{~m}$ quadrat $\left(\mathrm{n}^{\circ} 2\right)$ was established to sample plant shoot biomass (Bedunah et al., 1995). In the middle of frame $\mathrm{n}^{\circ} 2$, the mesofauna was sampled inside an $0.1 \times 0.1 \mathrm{~m}$ frame $\left(\mathrm{n}^{\circ} 3\right)$ according to the ISO $23611-2$ standard. Around the mesofauna sampling frame, four $0.1-\mathrm{m}$ deep samples of $0.1 \times 0.1 \mathrm{~m}\left(\mathrm{n}^{\circ} 4\right)$ were pooled into one composite sample for physico-chemical and microbiological analyses. The macrofauna was sampled by hand sorting in a $0.25 \times 0.25 \times 0.30 \mathrm{~m}$ soil block ( $\left.{ }^{\circ} 5\right)$ directly adjacent to frame $\mathrm{n}^{\circ} 1$. Sampling, extracting and preserving macro-invertebrates from soils, including the litter zone, was done according to the normalized TSBF method for temperate regions (ISO 23611-5). Samples were either dried immediately for physical and chemical analyses (lyophilized for organic pollutant analysis) and plant biomass measurements, frozen within the day of sampling for microbiology analyses, stored at $4^{\circ} \mathrm{C}$ and analysed within a week for microbial activity and macrofauna measurements, and mesofauna was extracted within the day.

\subsection{Abiotic parameters}

As regards abiotic parameters, 11 variables that quantify soil fertility (organic matter (OM), waterholding capacity (WHC), clay content, exchangeable calcium $(\mathrm{Ca})$, potassium $(\mathrm{K})$, magnesium $(\mathrm{Mg})$ and sodium $(\mathrm{Na})$ cations, Olsen phosphorus $(\mathrm{P}), \mathrm{pH}$, cation exchange capacity (CEC), carbon:nitrogen $(\mathrm{C}: \mathrm{N})$ ratio) and 4 pollution variables $(\mathrm{PAH}$ and available cadmium $(\mathrm{Cd})$, zinc $(\mathrm{Zn})$ and lead $(\mathrm{Pb})$ concentrations) were measured. The time span since the last anthropogenic action was also taken into account. 


\subsubsection{Fertility parameters}

The following usual agronomic parameters were analysed using normalized methods: granulometry (NF X 31-107), from 2-mm sieved soil (Soil Analysis Laboratory of Arras, France); pH, from $20 \mathrm{~g}$ of fresh soil in distilled water with a 1:5 ratio (v/w) (ISO 10390); CEC using cobaltihexamine extraction (NF X 31-130); WHC (ISO 11267 - Annex B); total carbon, total nitrogen and organic carbon (assessed by combustion after decarbonation for organic carbon) (ISO 10694), and available phosphorus (using Olsen method) (NF ISO 11263). Pseudo-total metallic trace elements were measured by inductively coupled plasma with optical emission spectroscopy (ICP-OES) after soil aqua regia digestion (ISO NF 11466). Exchangeable cations were extracted following the cobaltihexamine method (NF X 31-130) and analysed by ICP-OES (ISO 22036). All analyses were performed using certified reference material and control charts.

\subsubsection{Pollutant concentrations}

To quantify potential soil pollution, metallic trace elements and $\mathrm{PAHs}$ were analysed. $\mathrm{CaCl}_{2}$, diethylenetriaminepentaacetic acid (DTPA)-extractable (NF EN 13651) and pseudo-total metallic trace elements (ISO NF 11466) were measured by ICP-OES. PAHs were extracted from $2 \mathrm{~g}$ of lyophilized soil, using a high-pressure and high-temperature automated extractor DIONEX ${ }^{\circledR} 200$ accelerated solvent extractor (ASE) with dichloromethane. Dichloromethane was removed by evaporation under a nitrogen flow, and acetonitrile was added for analysis. The 16 US-EPA PAHs were measured using a high-pressure liquid chromatography (HPLC, Dionex Ultimate 3000) system with a UV detector $(254 \mathrm{~nm})$. The low-molecular (2-3 cycles), intermediary (4-5 cycles) or highmolecular weight ( 6 cycles) PAHs were present in the same proportions in all soils, so we chose to present the sums of the 16 PAHs concentrations.

\subsection{Biotic parameters}

The density and richness of the biotic components (microbial, mesofauna, macrofauna and herbaceous communities) and mycorrhizal colonization frequency were measured.

\subsubsection{Bacterial and fungal density and community structure}

We measured the abundance and richness of soil micro-organisms in the composite soil samples $n^{\circ} 4$ (Fig. 2). Nucleic acids were extracted from $0.5 \mathrm{~g}$ of fresh, 2-mm sieved soil with a FastDNA SPIN Kit for Soil (MP Biomedicals), and suspended in $100 \mu \mathrm{L}$ of DES (Dnase-free water). Total DNA concentrations and quality (A260/A280 purity ratio) were measured using a spectrophotometer (UV1800, Shimadzu) equipped with a TrayCell unit (Hellma). To quantify bacterial and fungal density in the six soils, a real-time polymerase chain reaction (PCR) was performed according to Cébron et al. (2008) and Thion et al. (2012) respectively. Bacteria and fungi were quantified by 
targeting 16S rRNA and 18S rRNA using the primer sets 968F/1401R (Felske et al., 1998) and Fung5F/FF390R (Lueders et al., 2004), respectively. Amplification reactions were carried out in a 20$\mu \mathrm{L}$ volume, using iQ SYBR green SuperMix (Bio-Rad), and quantification was performed using an iCycler Optical System (Bio-Rad).

The bacterial and fungal community structures of the six soils were estimated by denaturing gradient gel electrophoresis (DGGE). General PCR reactions were carried out in $50-\mu \mathrm{L}$ reaction volumes containing $1 \times \mathrm{PCR}$ buffer (Invitrogen) supplemented with $1.5 \mathrm{mM} \mathrm{MgCl}_{2}, 200 \mu \mathrm{M}$ of each dNTP (Fermentas), $0.2 \mu \mathrm{M}$ of each primer (MWG-Biotech), $1.25 \mathrm{U}$ of recombinant Taq DNA Polymerase (Invitrogen), and $1 \mu \mathrm{L}$ of template DNA. For bacteria, a fragment of the 16S RNA gene was amplified using primers F984-gc/R1378 (Heuer et al., 1997). The bacterial DGGE gradient contained 45 to $60 \%$ of denaturant ( $100 \%$ denaturant was defined as $40 \%$ (v/v) formamide and $7 \mathrm{M}$ urea). For fungi, a fragment of the 18S RNA gene was amplified using primers FR1-gc/FF390 (Vainio and Hantula, 2000). The fungal DGGE gradient contained $40-55 \%$ of denaturant. Image analyses of the DNA profiles and band intensities were obtained using Quantity One ${ }^{\circledR}$ (version 4.6.9; Bio-Rad Laboratories). The richness of each sample was estimated from the number of ribotypes.

\subsubsection{Mycorrhizal colonization}

We estimated root colonization by arbuscular mycorrhizal fungi, which are symbiotic fungi associated to the roots of most plant species (Smith and Read 2008). The root systems collected in samples $n^{\circ} 4$ (Fig. 2) were washed, and thirty 1-cm root segments were picked randomly. These root fragments were stained with Trypan blue (Koske and Gemma, 1989) and scored for the percentages of colonization by arbuscular mycorrhizal fungi according to the protocol described in Trouvelot et al. (1986).

\subsubsection{Mesofauna density and richness}

More than $90 \%$ of Collembola inhabit the top $10 \mathrm{~cm}$ of soil so $10-\mathrm{cm}$ deep soil cores were considered as sufficient to sample most of the soil Collembola (Fountain and Hopkin, 2004). Collembola were sampled using two $5-\mathrm{cm}$ diameter and 5-cm deep corers in sample $\mathrm{n}^{\circ} 3$ (Fig. 2). The micro-arthropods were extracted from the 10 corers per site using a high-temperature gradient extractor (Macfadyen, 1961). After extraction, they were transferred to a $70 \%(\mathrm{v} / \mathrm{v})$ ethanol solution for conservation. Then they were bleached using chloral-lactophenol, counted to determine their density, and identified down to the species level using Hopkin's key (Hopkin, 2007) to determine species richness.

\subsubsection{Macrofauna study}

The soil macrofauna component was studied by excavating $0.25 \times 0.25 \times 0.30 \mathrm{~m}$ soil blocks in sample $\mathrm{n}^{\circ} 5$. The macrofauna was hand-sorted in laboratory, and the organisms were kept in a $70 \%(\mathrm{v} / \mathrm{v})$ 
ethanol solution. They were identified down to the family level. Ants were removed from the analysis because these social insects are highly aggregated in space (Nahmani and Rossi 2003).

\subsubsection{Herbaceous plant biomass and richness}

Herbaceous plant richness (number of genuses or families) was quantified in the $1 \mathrm{x} 1 \mathrm{~m}^{2}$ area of sample $\mathrm{n}^{\circ} 1$ (Fig. 2). Shoots of herbaceous plants were sampled in an $0.5 \times 0.5-\mathrm{m}^{2}$ area (sample $\mathrm{n}^{\circ} 2$, Fig. 2), dried for 3 days at $70^{\circ} \mathrm{C}$ and then weighted for biomass quantification.

\subsection{Functional parameters}

As regards functional parameters, decomposition was studied through fluorescein diacetate (FDA) hydrolysis, alkaline phosphatase activity, urease activity, average mineralization capacity (AMC), macro-decomposer and meso-decomposer relative abundance levels, and organic pollutant degradation by quantifying bacterial PAH-degradation genes.

\subsubsection{Microbial functions}

Enzymes are good proxies of the soil biological activity, and even considered as a component of the soil biodiversity (Caldwell, 2005). To study the potential decomposition process in the ecosystem, we quantified enzymatic activities involved in the phosphorus and nitrogen cycles, including alkaline phosphatase (Marx et al., 2001) and urease (Sinsabaugh et al., 2000), respectively, from sample ${ }^{\circ} 4$. To assess global activity (ubiquitous esterase, lipase and protease activities), FDA hydrolysis was measured (Green et al., 2006).

Most soil microorganisms are heterotrophs and play an important part in organic compound mineralization. Potential microbial mineralization activity was assessed using a MicroResp ${ }^{\mathrm{TM}}$ system (Campbell et al., 2003). For each sample, eight wells of a 96-deep-well plate were filled with fresh 2mm sieved soil and 9 carbon sources were added: L-arginine (Sigma), glycine (Sigma), D(-) fructose (Sigma), D (+) galactose (Rectapur), cellulose (Sigma), alkali lignin (Aldrich), L-cysteine (Amresco), $\mathrm{D}(+)$ glucose monohydrate (Sigma), phenylalanine (Sigma), or distilled water for basal respiration. Detection microplates, were read in a spectrophotometer (Safas Monaco Xenius XC) at $570 \mathrm{~nm}$ absorbance wavelength $\left(\mathrm{T}_{0}\right)$ (Campbell et al., 2003). Then, they were placed on a MicroResp ${ }^{\mathrm{TM}}$ seal, on top of deep-well plates containing the soils and carbon sources or distilled water. After incubation for $5.4 \pm 1.1 \mathrm{~h}$ (depending on the substrate) at $25^{\circ} \mathrm{C}$, the plates were removed and read again in the spectrophotometer. The color development rates were calculated from the difference between absorbance values at $5.4 \pm 1.1 \mathrm{~h}$ and at $\mathrm{T}_{0}$ for each well, and the values were transformed to quantity of produced $\mathrm{CO}_{2}$. The means of the activities based on the 9 substrates were calculated and they represented the $\mathrm{AMC}$ of each sample. 
The potential degradation capacity of PAHs in the soils was estimated by quantifying the Grampositive (GP) and Gram-negative (GN) bacterial PAH-degrading gene from sample ${ }^{\circ} 4$. To that end, a real time PCR was performed (Cébron et al., 2008). The two groups of PAH degraders were quantified by targeting PAH-ring hydroxylating dioxygenase genes using the primer sets PAH-RHD $\alpha$ GP and GN (Cébron et al., 2008). Amplification reactions were carried out in a $20-\mu \mathrm{L}$ volume, using iQ SYBR green SuperMix (Bio-Rad), and quantification was performed using an iCycler Optical System (Bio-Rad). Results were expressed as the proportion of bacterial PAH-degrading gene copies relatively to the $16 \mathrm{~S}$ gene copies, i.e. the ratio between $\mathrm{PAH}$ degraders and bacterial density.

\subsubsection{Functions of the fauna}

Trophic groups are classified into 4 categories: phytophageous, zoophageous, geophageous, and decomposers (Pey et al., 2014). Because we focused on the decomposition process, we only used the community-weighted mean (CWM) of decomposers referred to as "proportion of meso- or macrodecomposers". For each species, the data was coded into an affinity percentage score for each attribute. In the end, each soil had a total community composed of a percentage of each attribute. The CWM was obtained using equation 1 (Garnier et al., 2004), where $P i$ is the relative abundance of species $i, n$ is the number of Collembola species or macrofauna families/orders, and Decomposer $r_{i}$ is the relative decomposer diet of species $i$.

$$
C W M=\sum_{i=1}^{n} P_{i} \times \text { Decomposer }_{i}
$$

\subsection{Statistical analyses}

R Software (version 3.1.3, Development Core Team, 2015) was used for data processing. To study differences among soils and after checking normality and variance homogeneity using Shapiro Wilk's test and Bartlett's test, one-way ANOVA was performed, followed by Tukey's HSD test for paired comparisons in parametric tests $(\mathrm{P}<0.05)$ for $\mathrm{WHC}$, FDA hydrolysis, alkaline phosphatase activity, macrofauna density, Collembola richness, bacterial abundance, relative GP bacterial abundance, AMC, mycorrhizal colonization, meso-decomposer relative abundance, bacterial and fungal community structure. Kruskal-Wallis test $(\mathrm{P}<0.05)$ was used when parametric conditions were not met, for multiple comparisons of rank distribution, for exchangeable cations $\mathrm{Ca}, \mathrm{K}, \mathrm{Mg}$ and $\mathrm{Na}$, available $\mathrm{Cd}, \mathrm{Zn}$ and $\mathrm{Pb}$, Olsen $\mathrm{P}, \mathrm{pH}, \mathrm{CEC}, \mathrm{C}: \mathrm{N}$ ratio, $\mathrm{OM}$ content, $\mathrm{PAH}$ concentrations, plant biomass and richness, urease, macro-decomposer relative abundance, macrofauna richness, Collembola density, fungal abundance, and relative GN bacterial abundance parameters. The CWM of decomposers was calculated using the FD package in R (Laliberté et al., 2014). Significant differences were considered for $\mathrm{P}<0.05$; $\mathrm{P}$-values are indicated for each measured variable in Table 1 . Linear 
regression were tested via the lmtest package in $\mathrm{R}$, and correlations were represented by the Pearson correlation coefficient (Hothorn et al., 2015).

Multivariate analyses were performed to show the co-variation between abiotic and biotic or functional parameters. We used the ade4 package in R (Dray and Dufour, 2007). Firstly, a Principal Component Analysis (PCA1) was performed on 16 abiotic variables (OM, WHC, clay content, exchangeable cations $\mathrm{Ca}, \mathrm{K}, \mathrm{Mg}$ and $\mathrm{Na}$, available $\mathrm{Cd}, \mathrm{Zn}$ and $\mathrm{Pb}$, Olsen phosphorus, $\mathrm{pH}, \mathrm{CEC}, \mathrm{C}: \mathrm{N}$, PAH concentrations, and soil age, from the date of the last anthropogenic action). A second PCA (PCA2) was performed on 11 biotic variables (bacterial abundance and richness, fungal abundance and richness, mycorrhizal colonization frequency, macrofauna density and richness, Collembola density and richness, plant biomass and richness). Finally, a third functional PCA (PCA3) was performed with 8 decomposition- and degradation-linked variables (FDA hydrolysis, alkaline phosphatase activity, AMC, urease activity, macro-decomposer relative abundance, meso-decomposer relative abundance, and relative abundance levels of the GP and GN bacterial PAH-degrading genes). Co-inertia analyses were performed to analyse (i) co-variation of abiotic and biotic parameters (PCA1PCA2) and (ii) co-variation of abiotic and functional parameters (PCA1-PCA3) to identify similar structures in the dataset according to abiotic, biotic, and functional parameters.

\section{Results and discussion}

\subsection{Abiotic characteristics of the soils}

\subsubsection{Fertility parameters}

The six soils exhibited contrasting fertility parameters (Table 1). The highest clay content was in soil $\mathrm{B}$, i.e. the non-hazardous waste landfill, probably due to fine construction and demolition waste contained in the landfill process, that was likely to be of clay size (Rodrigues et al., 2013). The OM content was significantly higher (an average $39.7 \%$ ) in soil A (an experimental constructed soil) than in the other 5 soils. In soil A, the original addition of OM mainly under the form of compost during construction (Séré et al., 2008) could explain the higher OM content. Soils B, E and F had OM contents comparable to grassland soil (4.3\%) and soils of urban, industrial, traffic, mining and military areas (SUITMA) (6 to 8\%) (Mao et al., 2014; Joimel et al., 2016). The OM concentration in soil C (coking plant soil) was comparable to other coking plant soils (12 to 17\%, Biache et al., 2008). The organic contaminants in soils A, C, D and E may have contributed to their OM content, but were not sufficient to explain differences in OM content since they all contained PAH concentrations in the same order of magnitude. WHC was significantly higher in soil A (Table 1) than in the other soils, probably because of the presence of OM and paper-mill sludge (Rawls et al., 2003). Although clay plays a role in WHC (Roberts et al., 2006), no relationship was found between these parameters for these soils. All 6 soils had a high $\mathrm{C}: \mathrm{N}$ ratio, for example as compared to the $\mathrm{C}: \mathrm{N}$ ratio of grasslands 
(around 10 according to Stauffer et al. (2014) and Ponge et al. (2013)) or to coal mine reclaimed land soils (Ingram et al., 2005). However, the C:N values of our soils were in the range of values found in coking plant soils (Biache et al., 2008) and in a landfill with illicit materials rich in metal contaminants including metallurgic slags, tailings and ashes (Dermont et al., 2010). This suggests either resistant organic components or lower nitrogen contents in these soils. Soil D (settling pond soil) had the highest $\mathrm{C}: \mathrm{N}$ ratio as compared to the other soils, maybe in link with the anthropogenic origin of the organic carbon in the parent material (steel sludge) associated with a poor nitrogen content (Dermont et al., 2010). Thus, the decomposition rate, represented by AMC, was very low in this soil. The soils were all alkaline (pH 7.9 on average) with maximum $\mathrm{pH}$ values of 8.4 and 8.3 for soils D and F, respectively. In urban and industrialized areas, waste inputs under the form of gravel, rubble and concrete, have been shown to induce alkalinisation (Morel et al., 2005; Rokia et al., 2014). All six soils had a low CEC ranging between 10 and $22 \mathrm{cmol}^{+} \cdot \mathrm{kg}^{-1}$, so a lower capacity to hold nutrients as compared to grasslands $\left(35 \mathrm{cmol}^{+} \cdot \mathrm{kg}^{-1}\right.$; Stauffer et al., 2014) and to park or garden soils in urban areas $\left(32 \mathrm{cmol}^{+} . \mathrm{kg}^{-1}\right.$; Santorufo et al., 2014). CEC was the lowest in soils D (settling pond) and $\mathrm{F}$ (constructed and contaminated). For soil $\mathrm{F}$, this corresponded to the low CEC values of the contaminated sludge and biopile-treated soil (4.7 and $7.5 \mathrm{cmol}^{+} . \mathrm{kg}^{-1}$, respectively) that were analysed separately. For settling pond soils, a large range of values have been reported, from 10 (Cerqueira et al., 2012) to 51.4 (Huot et al., 2011) $\mathrm{cmol}^{+} \cdot \mathrm{kg}^{-1}$, possibly due to different waste origins and compositions, such as iron waste and by-products or sludge from copper extraction, respectively. The highest CEC was found in soil A; it reflected the CEC value of the initially added green waste compost (42.5 $\mathrm{cmol}^{+} \cdot \mathrm{kg}^{-1}$; Sere et al., 2008).

Phosphorous concentration was significantly higher in soil A $\left(62 \mathrm{mg} \cdot \mathrm{kg}^{-1}\right)$ than in the other soils, probably due to the added green waste compost, with an originally available phosphorous content of 670 mg.kg ${ }^{-1}$ (Sere et al., 2008). Phosphorous is a dominant element in construction and demolition waste material (Butera et al., 2014) but may not be available. This could explain the low available phosphorous concentration in soil $\mathrm{B}$. The available phosphorous concentrations of the six soils were in the same order of magnitude as in SUITMA soils and grassland (45 and $31 \mathrm{mg} \cdot \mathrm{kg}^{-1}$, respectively, Joimel et al. (2016)). Among the six soils, the settling pond soil D had the significantly highest exchangeable $\mathrm{Ca}$ and $\mathrm{Mg}$ concentrations, with 2,031 mg.kg ${ }^{-1}$ and $312 \mathrm{mg} \cdot \mathrm{kg}^{-1}$, respectively. High Ca and $\mathrm{Mg}$ concentrations were also found in another settling pond soil, composed of steel sludge notably rich in $\mathrm{Ca}$ (Huot, 2013). Soil A contained a higher exchangeable $\mathrm{K}$ concentration than the others, brought by the green waste compost (Séré, 2007). The exchangeable Na concentration was lower in the coking plant soils $\mathrm{C}$ and $\mathrm{E}$ than in the other soils, and was the highest in soil F (55 mg. $\left.\mathrm{kg}^{-1}\right)$, suggesting a salinity problem in this constructed Technosol, as often reported in derelict soils (Wong and Bradshaw, 2003). 
Soil A appeared to be the most fertile based on abiotic parameters, with a high OM content and a high available phosphorous concentration. Conversely, soils B, D and F seemed to be the least fertile, with low OM contents and low phosphorous concentrations. Soils $\mathrm{C}$ and $\mathrm{E}$ had intermediate fertility parameters as compared to the other ones.

\subsubsection{Pollutant concentrations}

Soils $\mathrm{A}, \mathrm{C}, \mathrm{D}$ and $\mathrm{F}$ had total $\mathrm{Cd}, \mathrm{Pb}$ and $\mathrm{Zn}$ concentrations above natural geochemical backgrounds (Darmendrail et al., 2000) following soil contamination by uncontrolled coking plant and steel production activities (Rachwal et al., 2015). However, $\mathrm{Cd}, \mathrm{Zn}$ and $\mathrm{Pb}$ concentrations were low as compared to values found in metal-polluted soils (Dudka and Adriano, 1997). Soil F had the highest available $\mathrm{Cd}, \mathrm{Pb}$ and $\mathrm{Zn}$ concentrations (Table 1), because the contaminated sludge contained high metal concentrations, i.e. total concentrations of $284(\mathrm{Cd}), 5,108(\mathrm{~Pb})$ and 23,630 (Zn) mg.kg ${ }^{-1}$. Soils B and $\mathrm{E}$ exhibited low metal contamination. The landfill in soil B had been constructed with noncontaminated materials. Although E soil was located on a coking plant site, the sampling was performed in the former gas condensation and extraction area, which was not a potential source of metal contamination.

PAH concentrations in the soils were moderate, indicating slight contamination. Anthropic soils can contain PAH concentrations beyond 1,000 mg.kg ${ }^{-1}$ (Biache et al., 2008; Ouvrard et al., 2013). But PAH concentrations can largely vary in soils from coking plant sites owing to contamination heterogeneity, age, natural attenuation with time, and to remediation measures (Bourceret et al., 2015). Due to the associated risks, highly PAH-contaminated soils cannot be left unused and have to be remediated or excavated. Therefore, derelict soils should have low or poorly available pollutant concentrations in order to be considered as a resource. PAH concentrations in our 6 soils were indeed low, below $200 \mathrm{mg} \cdot \mathrm{kg}^{-1}$, and statistically the lowest in soils B and F (Table 1). As already mentioned, soil B materials must be non-contaminated to be used in non-hazardous waste landfill. Soil $\mathrm{F}$ contained low PAH concentrations, because biopile treatment had been applied to eliminate these organic contaminants. The presence of $170 \mathrm{mg} \cdot \mathrm{kg}^{-1}$ of PAHs in the constructed soil A was surprising since green-waste compost and paper mill waste should be devoid of PAH contamination and the remediated soil had a low PAH concentration (46 mg. $\mathrm{kg}^{-1}$; Séré, 2007). This PAH concentration may have been concentrated from the remediated soil toward the topsoil OM or have originated from aerial deposits (Desalme et al., 2011). The presence of PAHs in the other soils (C, D and E) was linked to past industrial activities that generated organic contamination. We did not measure the available fraction of PAHs. However, in historically contaminated soils, such as coking plant soils, it is generally low due to aging (Ouvrard et al., 2011; Barnier et al., 2014). 


\subsection{Biological characteristics of the derelict soils}

\subsubsection{Microorganisms}

Bacterial density was in the same order of magnitude in the six soils, and was in line with data from grasslands and brownfields $\left(1.8 \times 10^{10}\right.$ and $1.6 \times 10^{10} 16 \mathrm{~S}$ rDNA gene copy numbers per $\mathrm{g}$ of dry soil, Cluzeau et al., 2012). Fungal density was in the same order of magnitude as in coking plant wasteland $\left(1-5 \times 10^{8} 18 \mathrm{~S}\right.$ rDNA gene copy number per $\mathrm{g}$ of dry soil, Bourceret et al., 2016). But we evidenced significant differences between our soils. Bacterial gene density was significantly higher in soils A and $\mathrm{C}$ than in the other four soils (Table 1). The abundance of fungal genes was also higher in soil A, then in soils $\mathrm{C}$ and $\mathrm{E}$, than in the other soils. Microbial density was correlated with $\mathrm{OM}$ content $\left(\mathrm{R}^{2}=0.51\right.$, $\mathrm{P}<0.001$ for bacterial density and $\mathrm{R}^{2}=0.44, \mathrm{P}<0.001$ for fungal density) and WHC $\left(\mathrm{R}^{2}=0.45, \mathrm{P}<0.001\right.$ for bacteria and $\mathrm{R}^{2}=0.64, \mathrm{P}<0.001$ for fungi). Such correlations were reported previously in urban soils $(\mathrm{R}=0.63$ and $\mathrm{R}=0.39$ for organic carbon content and $\mathrm{WHC}$ respectively, Yang et al., 2006) and in a post-fire ecosystem ( $\mathrm{R}=0.83$ for organic carbon content; Muñoz-Rojas et al., 2016). The negative correlation between microbial density and the $\mathrm{C}: \mathrm{N}$ ratio, and the positive correlation between nitrogen concentrations and bacterial $\left(\mathrm{R}^{2}=0.60 ; \mathrm{P}<0.001\right)$ and fungal $\left(\mathrm{R}^{2}=0.56 ; \mathrm{P}<0.001\right)$ densities suggest that nitrogen is a limiting factor for microbial growth in these soils.

Bacterial and fungal richness was higher in soil $\mathrm{C}$ than in the other ones (average values of 16 dominant bands for bacteria and 7.4 dominant bands for fungi). Soils A and F harboured the lowest microbial richness. In soil F, the low OM content and metal contamination could explain the low microbial diversity (Chodak et al., 2013). In soil A, the high OM content may have boosted growth of a few dominant taxa and limited growth of the other taxa (Torsvik and Sørheim, 2002).

Plant roots were highly colonized by arbuscular mycorrhizal fungi, with a mean of $84 \pm 13 \%$ mycorrhizal root frequency for the six soils, yet with slight differences among the soils. The mycorrhizal colonization rate was slightly but significantly lower in soil F than in soils B and E (Table 1). These differences could be related to metal pollutants since soil $F$ had the highest total and available $\mathrm{Cd}, \mathrm{Zn}$ and $\mathrm{Pb}$ concentrations. Arbuscular mycorrhizal association is a widespread terrestrial symbiosis that involves $80-85 \%$ of vascular plants (Meier et al., 2012). It is beneficial to plants, especially in stressed environments (Miransari, 2010). This high level of symbiosis indicated an absence of metal toxicity in the soils, since arbuscular mycorrhizal colonization is negatively affected by metal pollution (Vogel-Mikuš et al., 2005). The presence of arbuscular mycorrhizal fungi in metalpolluted soils has been extensively shown (e.g. Del Val et al., 1999), as well as their potential role in reducing metal toxicity to plants. It is also a key indicator of soil quality (Gianinazzi et al., 2006). 


\subsubsection{Fauna}

Collembola density was maximal in soil $\mathrm{D}$ with 91,000 individuals per $\mathrm{m}^{2}$ (Table 1) and was significantly higher than in soils $\mathrm{A}, \mathrm{B}$ and $\mathrm{E}$. It was correlated with the soil exchangeable $\mathrm{Ca}\left(\mathrm{R}^{2}=0.48\right.$; $\mathrm{P}<0.001)$ and $\mathrm{Mg}\left(\mathrm{R}^{2}=0.40 ; \mathrm{P}<0.001\right)$ concentrations. Such a relationship between Collembola and exchangeable cations (Cassagne et al., 2003) or litter quality, notably $\mathrm{Ca}$ and $\mathrm{Mg}$ contents (Rizvi et al., 2012) has already been observed. Collembola density in our six soils was 1.4 to 7.5 times higher than in meadow (12,103 ind. $\mathrm{m}^{-2}$; Cluzeau et al., 2012), SUITMA (around 11,616 ind. $\mathrm{m}^{-2}$; Joimel et al., 2017), or urban soils (5,000 to 15,000 ind. $\mathrm{m}^{-2}$; Santorufo et al., 2014). Thus, derelict soils seem to be a favourable habitat for Collembola, especially those with high exchangeable $\mathrm{Ca}$ and $\mathrm{Mg}$ concentrations.

Collembola richness was significantly higher in soils D, E and F than in the other soils (Table 1). It was correlated with plant richness $\left(\mathrm{R}^{2}=0.44, \mathrm{P}<0.001\right)$. Sabais et al. (2011) also showed that plant species richness drove Collembola diversity in temperate grassland. However, they found a correlation between plant richness and Collembola density that we did not find in the present study. Likewise, Joimel (2015) showed a correlation between Collembola density and plant richness in an uncultivated ecosystem re-colonized by spontaneous vegetation. The response of Collembola to increased plant richness could be due to changes in abiotic factors. For example, mixed litters support more diverse communities than single species litters, because they provide higher habitat complexity and in turn higher diversity of food resources (Bardgett, 2002). Fauna diversity is less affected by soil properties than density (Nahmani and Lavelle, 2002; Santorufo et al., 2012). Soils A and B harboured the same Collembola richness as grassland (Cluzeau et al., 2012) or urban soils (Santorufo et al., 2014) but soils C, D, E and F harboured higher richness than these soils. Therefore, derelict soils offer a heterogeneous habitat likely to enhance soil animal diversity (Bardgett, 2002; Cole et al., 2006) and appear to be a biodiversity reserve of Collembola.

As for the macrofauna, soils A and B had the highest density and richness values (Table 1). The total macrofauna density was correlated with plant biomass $\left(\mathrm{R}^{2}=0.55, \mathrm{P}<0.001\right)$, probably due to the potential stock of plant litter and habitats that it represents for macrofauna communities. Cole et al. (2006) showed that earthworm and mesofauna density increased with an increase in plant productivity and suggested that soil biotic communities were mainly regulated by bottom-up forces. We also observed a high correlation between plant biomass and earthworm density $\left(\mathrm{R}^{2}=0.62, \mathrm{P}<0.001\right)$, and also with total macrofauna density. The presence of pollutants could influence invertebrate density and diversity. Several authors found decreased macrofauna density along with heavy metal contamination (Nahmani and Lavelle, 2002; Nahmani et al., 2005; Hedde et al., 2012). This decrease could contribute to explain results observed in soils C and F. Soils A and B contained the same macrofauna density as a meadow ecosystem (around 700 ind. $\mathrm{m}^{-2}$; Cluzeau et al., 2012) and open post-mining sites (around 570 ind. $\mathrm{m}^{-2}$; Frouz et al., 2013) and a higher density than an orchard ecosystem (around 440 
ind. $\mathrm{m}^{-2}$; Walmsley and Cerdà, 2017). A high correlation was found between macrofauna density and richness $\left(\mathrm{R}^{2}=0.72, \mathrm{P}<0.001\right)$. Reviews by Cole et al. (2006) and Bardgett (2002) stated that competitive interactions between macrofaunal species can be limited in soils with resource partitioning and niche differentiation, maintaining soil biodiversity despite increased density. As derelict soils offer a heterogeneous habitat, they provide for the highly potential co-existence of several different species.

\subsubsection{Herbaceous plants}

The biomass of aboveground plants was significantly higher in soils A and B than in the other soils, as opposed to plant diversity estimated from plant richness (Table 1). Plant biomass was correlated with the exchangeable $\mathrm{K}$ concentration $\left(\mathrm{R}^{2}=0.60 ; \mathrm{P}<0.001\right)$, which suggests a potassium limitation in the soils. Herbaceous plant richness was negatively correlated with plant biomass $\left(\mathrm{R}^{2}=0.54, \mathrm{P}<0.001\right)$. Nutrient deficiency and/or pollution affect the coexistence of plant species by limiting dominant plants and maintaining high plant diversity (Heinze et al., 2015). Shoot biomass and plant richness in these soils were similar to those of spontaneous urban habitats, with a mean of $0.34 \mathrm{~kg}$ of plant shoot per $\mathrm{m}^{2}$ and 14.7 species per $\mathrm{m}^{2}$ (Robinson and Lundholm, 2012). In comparison with urban habitats such as lawns and remnant natural areas (forests) (Robinson and Lundholm, 2012), aboveground biomass values in our derelict soils was low.

\subsection{Functional parameters of the derelict soils}

The meso-decomposer proportion was similar in the six soils, with $85 \pm 8 \%$ of the mesofauna community. Thus, our results showed no differences among the soils in trophic interactions at the mesofauna community scale. The proportion of macro-decomposers among the invertebrate community was significantly higher in soil A, B and E, than in soil D. Such proportions of macro- and meso-decomposers were also found in a non-polluted soil and in a forest ecosystem on polluted soil (Lucisine et al., 2015). This can be explained by the negative correlation between the proportion of macro-decomposers and Collembola density $\left(\mathrm{R}^{2}=0.46 ; \mathrm{P}<0.01\right)$. When Collembola density was low (soils A, B and E), the macro-decomposer proportion increased thanks to higher resource quantity and quality. For example, Grubert et al. (2016) recently found that the earthworm Lumbricus terrestris reduced the availability of litter nitrogen to other soil animal detritivores, in particular to Collembola Heteromurus nitidus.

As regards enzyme activity, the highest FDA hydrolysis activity level was in soil A. Cébron et al. (2011) showed that FDA hydrolysis increased with growing vegetation. Our results showed that the highest activity level was found in one of the soils with the highest plant biomass. However, no correlation was found between FDA hydrolysis and plant biomass. No correlation was found either with other parameters that could affect FDA hydrolysis, such as metal concentration (Li et al., 2009), soil texture (Vinhal-Freitas et al., 2017), or OM (Muscolo et al., 2014). Alkaline phosphatase activity 
was the highest in soils A and C. Significant correlations between alkaline phosphatase activity and abiotic parameters such as OM (Lucas-Borja et al., 2016), available phosphorous (Stauffer et al., 2014) and metal concentrations ( $\mathrm{Li}$ et al., 2009) have been reported. However, we found no correlation between alkaline phosphatase activity and other parameters. Urease activity was higher in A, C and E soils than in soils B, D and F. The presence of heavy metals can decrease urease activity (Thavamani et al., 2012), but we found no such relationship. However, we found a correlation between urease activity and bacteria density $\left(\mathrm{R}^{2}=0.57, \mathrm{P}<0.001\right)$, probably in relation to the soil nitrogen limitation. Enzyme activity in soil A was similar to the data obtained for the same enzymes in grassland (Stauffer et al., 2014). Similarly to enzyme activity, AMC was significantly higher in soil A, and the soils ranked as follows based on their mineralization capacity: $A>B=C>D=E=F$. AMC was strongly correlated with bacterial $\left(\mathrm{R}^{2}=0.60, \mathrm{P}<0.001\right)$ and fungal densities $\left(\mathrm{R}^{2}=0.58, \mathrm{P}<0.001\right)$. Other authors also found a correlation between microbial abundance (via the carbon content in the microbial biomass) and the soil basal respiration (Pavan Fernandes et al., 2005; Chodak et al., 2013). The carbon mineralization rate reflects OM availability to microorganisms (Stauffer et al., 2014) and has often been used as an indicator of soil biological functioning and quality (Schloter et al., 2003; Bastida et al., 2008; Muñoz-Rojas et al., 2016). Soil A displayed the highest biological functioning, whereas the $\mathrm{F}$ has the lowest.

We also studied the soil capacity to degrade PAH compounds. In the PAH-contaminated soils (A, C, $\mathrm{D}, \mathrm{E}$ ), the relative density of GP PAH-degrading genes represented 0.7 to $1.2 \%$, while it was significantly lower in soils B and F that displayed very low PAH concentrations, as shown previously by Cébron et al., (2008). The relative density of GN PAH-degrading genes was much lower than the density of GP PAH-degrading ones, as shown in PAH-polluted soils (Uyttebroek et al., 2006), and was slightly higher in soils A and E than in the other soils. According to Leys et al. (2005), lightmolecular-weight PAHs are mainly degraded by GN r-strategists. However, we found no difference in the concentrations of light-molecular-weight PAHs in soils A or E as compared to the other soils (data not shown).

\subsection{Co-variation between abiotic and biotic parameters in the derelict soils}

To compare the co-variation of abiotic and biotic parameters in the six soils, we carried out a first coinertia analysis (Fig. 3). The two projected inertias represented $81 \%$ of total inertia. The analysis showed a high co-variation between biotic and soil physico-chemical parameters ( $\mathrm{RV}=0.60$; MonteCarlo permutation test, $\mathrm{P}=0.001$ ). The soil samples, ordinated under abiotic or biotic parameters, were separated in four groups mainly along the first projected inertia axis (67\%): A; B; C and E; D and F.

Among the six soils, soil A (amended constructed soil) was characterized by higher values of WHC, $\mathrm{CEC}, \mathrm{K}$ and $\mathrm{OM}$ content and lower values of Ca content, $\mathrm{C}: \mathrm{N}$ ratio and age than the other soils. These 
abiotic parameters positively co-varied with microbial density (bacteria and fungi), and to a lower extent with plant biomass and richness and macrofauna density. The settling pond soil (D) and the heavy metal-contaminated constructed soil (F) grouped based on abiotic and biological parameters. These soils were also characterized by a high C:N ratio linked to high Collembola richness. Finally, the two coking plant soils $\mathrm{C}$ and $\mathrm{E}$ had close abiotic and biotic features. They were separated from soils A and B by the first axis and from soils D and F by the second axis. Age also appeared to be a discriminating parameter, with soils $\mathrm{A}$ and $\mathrm{B}$ the youngest, $\mathrm{D}$ and $\mathrm{F}$ intermediate, and $\mathrm{C}$ and $\mathrm{E}$ the oldest. The age parameter co-varied positively with plant richness but negatively with plant biomass, macrofauna density and richness. Different studies showed that soil colonization by living organisms after a disturbance is fast (Frouz et al., 2008; Dunger and Voigtländer, 2009; Thion et al., 2012; Lucas-Borja et al., 2016). In a field experiment with polluted soil and thermally treated soil, fungal communities seemed to have stabilized after 5 years (Thion et al., 2012). Plant and faunal communities also re-colonized disturbed soils rapidly. For example, Collembola communities settled a few months after soil waste deposition (Dunger et al., 2002), and earthworm communities after 5 years (Eijsackers, 2010). Plant and macrofauna components were present in post-mining soils in less than 15 years (Frouz et al., 2008).

The biotic parameters, that contributed to discriminate the six derelict soils, were plants, Collembola, macrofauna, bacterial and fungal density, and taxon richness of plants, Collembola and macrofauna. Several authors pointed out modifications of biological parameters along anthropogenic gradients, especially along a pollution gradient or with different land uses. For example, microbial biomass was affected by metal pollution (Kandeler et al., 2000), macrofauna density was lower in a highly polluted soil (Nahmani and Lavelle, 2002), Collembola communities were modified by land uses (Ponge et al., 2003) or an urbanization gradient (Kuznetsova, 2003). In the present study, although soils A and F differed in many parameters, there was no clear gradient of any parameter. None of the six soils was highly contaminated, so density/taxon richness seemed to be driven more by fertility parameters than by pollution. Several authors also showed that organism density or taxon richness were correlated with soil properties such as the $\mathrm{pH}$, the $\mathrm{OM}$ content or the water-holding capacity (Pižl et al., 2009; Santorufo et al., 2012; Muñoz-Rojas et al., 2016; Walmsley and Cerdà, 2017). However, most of the studies classified the soils or land uses according to only one biotic group (Ponge et al., 2003; Gulvik, 2007; Ruiz et al., 2011). All soils hosted a relatively high biodiversity, but differences in biotic parameters were observed among them. This raises the question of which parameter should be used to define the biological quality and the potential future use of derelict soils. 


\subsection{Co-variation between abiotic and functional parameters in the derelict soils.}

We performed another co-inertia analysis (Fig. 4) to analyse the functional and abiotic parameters of the soils. The two projected inertias represented $81 \%$ of total co-inertia, showing high co-variation of the functional and soil physico-chemical parameters $(\mathrm{RV}=0.64$; Monte-Carlo permutation test, $\mathrm{P}=0.002)$. The soils were mainly separated along the first projected inertia axis $(63 \%$ of total coinertia), discriminating soils A, B-C-E and D-F into 3 groups.

As in the previous analysis (Fig. 3), the amended constructed soil A was discriminated from the other soils along the $1^{\text {st }}$ co-inertia axis by higher macro-decomposer proportion, urease activity, FDA hydrolysis activity, AMC, and proportion of Gram-positive PAH-dioxygenase bacteria and the same abiotic parameters as in the first co-inertia analysis. As in figure 2, the settling pond soil D and the contaminated constructed soil $\mathrm{F}$ were opposite from soil A along the $1^{\text {st }}$ co-inertia axis. Both soils had a relatively low $\mathrm{AMC}$, related to their high $\mathrm{C}: \mathrm{N}$ ratio. Soils $\mathrm{B}, \mathrm{C}$ and $\mathrm{E}$ were separated from soil A by lower enzyme activity levels, macro-decomposer numbers and PAH degraders. However, they were discriminated along the second co-inertia axis (18\% of total co-inertia) by the $\mathrm{pH}, \mathrm{K}$, clay and age parameters and also by phosphatase activity and GN bacterial PAH degraders.

The soils differed by their functional parameters, especially relative macro-decomposer density, enzyme (urease, phosphatase and FDA hydrolysis) activity, AMC and both GP and GN microbial PAH degraders. As in the first co-inertia analysis, age appeared to be an important variable discriminating the soils, with $\mathrm{A}$ the oldest and $\mathrm{E}$ the youngest. However, the use of functional parameters separated soils $\mathrm{E}$ and $\mathrm{C}$ that were not discriminated using biotic parameters (Fig. 3). The functional parameters assessed in our study only referred to potential functions since enzyme activities and AMC were measured in laboratory conditions and not in situ. Likewise, we quantified the PAHdegrading gene but did not study gene expression; yet, a gene can be present without being expressed (Torsvik et al., 1996). As for microbial functions, the proportions of macro- and meso-decomposers also reflected potential functions since we used the community-weighted means based on literature data.

The two co-inertia analyses showed that several biotic and functional parameters discriminated the soils. Classifying these soils along a single biotic parameter gradient was not possible since most of the biotic parameters did not co-vary. For instance, some of the soils had a higher microbial density but lower plant richness although others had higher macrofauna richness but lower mesofauna density. In contrast, most of the functional parameters co-varied, suggesting that soils can be discriminated based on their relative decomposition functions. Thus, soil A appeared to have the highest level of functional parameters, due to $\mathrm{OM}$ and nutrient elements in the green-waste compost. The characteristics of the substrates and materials used for constructed soils may therefore be a key 
parameter for a potential re-use of the derelict soils. Soils F and D appeared to have the lowest levels of functional parameters. Soil $\mathrm{F}$ had a parent material poor in $\mathrm{OM}$ and nutrient elements, and a high $\mathrm{C}: \mathrm{N}$ ratio, with a high heavy metal content, leading to a low functional level. Soil D was characterized by a high $\mathrm{C}: \mathrm{N}$ ratio, suggesting a nitrogen limitation for microbial biomass and decomposition process. Clustering of the soils differed according to the parameters, whether biotic or functional. Soils $\mathrm{A}, \mathrm{D}$ and $\mathrm{F}$ were characterized in the same way whether based on biotic or functional parameters, but soils $\mathrm{B}, \mathrm{C}$ and $\mathrm{E}$ were not.

\subsection{Biotic interactions in the derelict soils}

Physico-chemical parameters strongly affected the biodiversity and functional parameters of the derelict soils, as shown in co-inertia analyses, but we wondered whether interactions between biological components could be identified and might affect soil quality and potential valorization. Indeed, as previously described, herbaceous plants richness was correlated with plant biomass, total macrofauna density was correlated with plant biomass, and Collembola richness was correlated with plant richness. Robinson and Lundholm (2012) underlined that plant abundance and variety in urban land appeared to support a more diverse invertebrate community than other habitats. As aboveground biota communities drive belowground biota communities, plant community composition strongly influences the community composition of belowground organisms and their activity (Wardle et al., 2004). In our study, the proportion of macro-decomposers was negatively correlated with collembola density and macrofauna density was correlated with macrofauna richness. There is a growing number of studies on influences of biotic interactions on soil biodiversity (Wardle, 2006; Wisz et al., 2013; Bardgett and Van Der Putten, 2014; Singh et al., 2014) and soil biotic communities are mainly regulated by bottom-up forces (Cole et al., 2006). Our results also show that biotic interactions play a role in community settlement. Therefore, biotic interactions in the derelict soils are related to, and should be considered to assess soil biological quality. However, the consequences of biotic and functional differing characteristics on the potential re-use of the derelict soils are not clearly known.

\section{Conclusion}

A comparison of abiotic, biotic and functional parameters in six soils highlighted that derelict soils are living soils, harbor a high soil biodiversity and can be functional for carbon mineralization and decomposition. The six soils displayed physico-chemical characteristics similar to urban soils, SUITMAs or grasslands, and most of them contained low contaminant concentrations. So their biodiversity was driven more by fertility parameters than by pollution. All biotic parameters, except the mycorrhizal colonization level, and functional parameters such as macro-decomposer proportion, enzyme activity, AMC, and microbial PAH degraders discriminated these derelict soils. The greenwaste compost-amended constructed soil displayed the highest quality in terms of fertility and 
functional parameters, while the settling pond soil and the heavy metal-contaminated constructed soils displayed the lowest (low fertility parameters and low functional levels). The two coking plant soils and the non-hazardous waste landfill soil displayed intermediate quality and different characteristics depending on biotic or functional parameters. These results support the emerging concept of multiple uses of soils, and the need to consider productivity parameters as well as broader abiotic, biotic and functional parameters. This study shows that certain derelict soils could be considered as a resource and have multiple uses such as supporting plant biomass production and harboring a biodiversity reserve.

\section{Acknowledgements:}

This work was carried out within the GISFI (www.gisfi.fr) within the framework of the LORVER project (www.lorver.org) funded by the French Lorraine Region and the European Regional Development Fund (ERDF). The authors wish to thank the technical staff of the GISFI, LIEC and LSE, particularly Alain Rakoto. 


\section{References:}

Amir, H., Jourand, P., Cavaloc, Y., Ducousso, M., 2014. Role of mycorrhizal fungi in the alleviation of heavy metal toxicity in plants, in: Mycorrhizal Fungi: Use in Sustainable Agriculture and Forestry. Volume 41. Soil Biology, pp. 241-258.

Anderson, E.C., Minor, E.S., 2017. Vacant lots: An underexplored resource for ecological and social benefits in cities. Urban For. Urban Green. 21, 146-152.

Anderson, J.M., Ingram, J.S.I., 1993. Tropical Soil Biology and Fertility-A Handbook of Methods. Soil Sci. 157, 265.

Bardgett, R., Van Der Putten, W.H., 2014. Belowground biodiversity and ecosystem functioning. Nature 515, 505-511.

Bardgett, R.D., 2002. Causes and consequences of biological diversity in soil. Zoology (Jena). 105, 367-374.

Bardgett, R.D., Wardle, D.A., 2010. Aboveground-belowground linkages: biotic interactions, ecosystem processes, and global change. Oxford University Press.

Barnier, C., Ouvrard, S., Robin, C., Morel, J.L., 2014. Desorption kinetics of PAHs from aged industrial soils for availability assessment. Sci. Total Environ. 470-471, 639-645.

Bastida, F., Zsolnay, A., Hernández, T., García, C., 2008. Past, present and future of soil quality indices: A biological perspective. Geoderma 147, 159-171.

Bedunah, D.J., Sosebee, R.E., for Range Management, S., 1995. Wildland plants: Physiological ecology and developmental morphology. Society for Range Management.

Biache, C., Mansuy-Huault, L., Faure, P., Munier-Lamy, C., Leyval, C., 2008. Effects of thermal desorption on the composition of two coking plant soils: Impact on solvent extractable organic compounds and metal bioavailability. Environ. Pollut. 156, 671-677.

Bonthoux, S., Brun, M., Di Pietro, F., Greulich, S., Bouché-Pillon, S., 2014. How can wastelands promote biodiversity in cities? A review. Landsc. Urban Plan. 132, 79-88.

Bourceret, A., Cébron, A., Tisserant, E., Poupin, P., Bauda, P., Beguiristain, T., Leyval, C., 2016. The bacterial and fungal diversity of an aged PAH- and heavy metal-contaminated soil is affected by plant cover and edaphic parameters. Microb. Ecol. 71, 711-724.

Bourceret, A., Leyval, C., De Fouquet, C., Cébron, A., 2015. Mapping the centimeter-scale spatial variability of PAHs and microbial populations in the rhizosphere of two plants. PLoS ONE, 10, e0142851.

Butera, S., Christensen, T.H., Astrup, T.F., 2014. Composition and leaching of construction and demolition waste: Inorganic elements and organic compounds. J. Hazard. Mater. 276, 302-311.

Caldwell, B.A., 2005. Enzyme activities as a component of soil biodiversity: a review. Pedobiologia (Jena). 49, 637-644.

Campbell, C.D., Chapman, S.J., Cameron, C.M., Davidson, M.S., Potts, J.M., 2003. A rapid microtiter plate method to measure carbon dioxide evolved from carbon substrate amendments so as to determine the physiological profiles of soil microbial communities by using whole soil. Appl. Environ. Microbiol. 69, 3593-3599.

Cassagne, N., Gers, C., Gauquelin, T., 2003. Relationships between Collembola, soil chemistry and humus types in forest stands (France). Biol. Fertil. Soils 37, 355-361.

Cébron, A., Cortet, J., Criquet, S., Biaz, A., Calvert, V., Caupert, C., Pernin, C., Leyval, C., 2011. Biological functioning of PAH-polluted and thermal desorption-treated soils assessed by fauna and microbial bioindicators. Res. Microbiol. 162, 897-907.

Cébron, A., Norini, M.P., Beguiristain, T., Leyval, C., 2008. Real-Time PCR quantification of PAHring hydroxylating dioxygenase (PAH-RHD $\alpha$ ) genes from Gram positive and Gram negative bacteria in soil and sediment samples. J. Microbiol. Methods 73, 148-159.

Cerqueira, B., Vega, F.A., Silva, L.F.O., Andrade, L., 2012. Effects of vegetation on chemical and mineralogical characteristics of soils developed on a decantation bank from a copper mine. Sci. Total Environ. 421-422, 220-229.

Chodak, M., Gołebiewski, M., Morawska-Płoskonka, J., Kuduk, K., Niklińska, M., 2013. Diversity of microorganisms from forest soils differently polluted with heavy metals. Appl. Soil Ecol. 64, 714.

Cluzeau, D., Guernion, M., Chaussod, R., Martin-Laurent, F., Villenave, C., Cortet, J., Ruiz-Camacho, 
N., Pernin, C., Mateille, T., Philippot, L., Bellido, A., Rougé, L., Arrouays, D., Bispo, A., Pérès, G., 2012. Integration of biodiversity in soil quality monitoring: Baselines for microbial and soil fauna parameters for different land-use types. Eur. J. Soil Biol. 49, 63-72.

Cole, L., Bradford, M.A., Shaw, P.J.A., Bardgett, R.D., 2006. The abundance, richness and functional role of soil meso- and macrofauna in temperate grassland-A case study. Appl. Soil Ecol. 33, 186-198.

Cundy, A.B., Bardos, R.P., Puschenreiter, M., Mench, M., Bert, V., Friesl-Hanl, W., Müller, I., Li, X.N., Weyens, N., Witters, N., Vangronsveld, J., 2016. Brownfields to green fields: Realising wider benefits from practical contaminant phytomanagement strategies. J. Environ. Manage. 186, $67-77$.

Dangi, S.R., Stahl, P.D., Wick, A.F., Ingram, L.J., Buyer, J.S., 2012. Soil microbial community recovery in reclaimed soils on a surface coal mine site. Soil Sci. Soc. Am. J. 76, 915-924.

Darmendrail, D.J., Barbier, J., Freyssinet, P., Mouvet, C., Salpéteur, I., Warver, P., 2000. Fonds géochimique naturel: Etat des connaissances à l'échelle nationale. Brgm/Rp-50518-Fr. 93.

Del Val, C., Barea, J.M., Azcón-Aguilar, C., 1999. Diversity of arbuscular mycorrhizal fungus populations in heavy-metal-contaminated soils. Appl. Environ. Microbiol. 65, 718-723.

Dermont, G., Bergeron, M., Richer-Laflèche, M., Mercier, G., 2010. Remediation of metalcontaminated urban soil using flotation technique. Sci. Total Environ. 408, 1199-1211.

Desalme, D., Binet, P., Epron, D., Bernard, N., Gilbert, D., Toussaint, M.L., Plain, C., Chiapusio, G., 2011. Atmospheric phenanthrene pollution modulates carbon allocation in red clover (Trifolium pratense L.). Environ. Pollut. 159, 2759-2765.

Development Core Team, R., 2015. A Language and Environment for Statistical Computing. Austria, Vienna : the R Foundation for Statistical Computing.

Doran, J.W., 2002. Soil health and global sustainability: Translating science into practice. Agric. Ecosyst. Environ. 88, 119-127.

Dray, S., Dufour, A.B., 2007. The ade4 Package: Implementing the Duality Diagram for Ecologists. J. Stat. Softw. 22, 1-20.

Dudka, S., Adriano, D.C., 1997. Environmental impacts of metal ore mining and processing: A review. J. Environ. Qual. 26, 590.

Dunger, W., Schulz, H., Zimdars, B., 2002. Colonization behaviour of Collembola under different conditions of dispersal. Pedobiologia (Jena). 46, 316-327.

Dunger, W., Voigtländer, K., 2009. Soil fauna (Lumbricidae, Collembola, Diplopoda and Chilopoda) as indicators of soil eco-subsystem development in post-mining sites of eastern Germany - a review. Soil Org. 81, 1-51.

Edrisi, S.A., Abhilash, P.C., 2016. Exploring marginal and degraded lands for biomass and bioenergy production: An Indian scenario. Renew. Sustain. Energy Rev. 54, 1537-1551.

Eijsackers, H., 2010. Earthworms as colonisers: Primary colonisation of contaminated land, and sediment and soil waste deposits. Sci. Total Environ. 408, 1759-1769.

Eyre, M.D., Luff, M.L., Woodward, J.C., 2003. Beetles (Coleoptera) on brownfield sites in England: An important conservation resource? J. Insect Conserv. 7, 223-231.

Felske, A., Wolterink, A., Lis, R. van, Antoon, D., Akkermans, L., 1998. Phylogeny of the main bacterial 16S rRNA sequences in drentse a grassland soils. Appl. Environ. Microbiol. 64, 871879.

Fountain, M.T., Hopkin, S.P., 2004. A comparative study of the effects of metal contamination on Collembola in the field and in the laboratory. Ecotoxicology 13, 573-587.

Frouz, J., Jílková, V., Cajthaml, T., Pižl, V., Tajovský, K., Háněl, L., Burešová, A., Šimáčková, H., Kolaříková, K., Franklin, J., Nawrot, J., Groninger, J.W., Stahl, P.D., 2013. Soil biota in postmining sites along a climatic gradient in the USA: Simple communities in shortgrass prairie recover faster than complex communities in tallgrass prairie and forest. Soil Biol. Biochem. 67, 212-225.

Frouz, J., Pižl, V., Tajovský, K., 2007. The effect of earthworms and other saprophagous macrofauna on soil microstructure in reclaimed and un-reclaimed post-mining sites in Central Europe. Eur. J. Soil Biol. 43, 184-189.

Frouz, J., Prach, K., Pižl, V., Háněl, L., Starý, J., Tajovský, K., Materna, J., Balík, V., Kalčík, J., Rehounková, K., 2008. Interactions between soil development, vegetation and soil fauna during 
spontaneous succession in post mining sites. Eur. J. Soil Biol. 44, 109-121.

Gange, A.C., Brown, V., 2002. Soil food web components affect plant community structure during early succession. Ecol. Res. 17, 217-227.

Gardiner, M.M., Burkman, C.E., Prajzner, S.P., 2013. The value of urban vacant land to support arthropod biodiversity and ecosystem services. Environ. Entomol. 42, 1123-1136.

Garnier, E., Cortez, J., Billès, G., Navas, M., Roumet, C., 2004. Plant functional markers capture ecosystem properties during secondary succession. Ecology 85, 2630-2637.

Garrigues, E., Corson, M.S., Angers, D.A., van der Werf, H.M.G., Walter, C., 2012. Soil quality in Life Cycle Assessment: Towards development of an indicator. Ecol. Indic. 18, 434-442.

Gessner, M.O., Chauvet, E., 2002. A case for using litter breakdown to assess functional stream integrity. Ecol. Appl. 12, 498-510.

Gianinazzi, S., Plumey-Jacquot, E., Gianinazzi-Pearson, V., Leyval, C., 2006. Contribution of arbuscular mycorrhiza to soil quality and terrestrial ecotoxicology, in: Microbiological Methods for Assessing Soil Quality. CABI, Wallingford, pp. 248-256.

Green, V.S., Stott, D.E., Diack, M., 2006. Assay for fluorescein diacetate hydrolytic activity: optimization for soil samples. Soil Biol. Biochem. 38, 693-701.

Grubert, D., Butenschoen, O., Maraun, M., Scheu, S., 2016. Understanding earthworm - Collembola interactions and their importance for ecosystem processes needs consideration of species identity. Eur. J. Soil Biol. 77, 60-67.

Gulvik, M.E., 2007. Mites (Acari) as indicators of soil biodiversity and land use monitoring: a review. Polish J. Ecol. 55, 415-440.

Hafeez, F., Martin-Laurent, F., Béguet, J., Bru, D., Cortet, J., Schwartz, C., Morel, J.L., Philippot, L., 2012. Taxonomic and functional characterization of microbial communities in Technosols constructed for remediation of a contaminated industrial wasteland. J. Soils Sediments 12, 13961406.

Hedde, Van Oort, F., Lamy, I., 2012. Functional traits of soil invertebrates as indicators for exposure to soil disturbance. Environ. Pollut. 164, 59-65.

Heinze, J., Bergmann, J., Rillig, M.C., Joshi, J., 2015. Negative biotic soil-effects enhance biodiversity by restricting potentially dominant plant species in grasslands. Perspect. Plant Ecol. Evol. Syst. $17,227-235$.

Heuer, H., Krsek, M., Baker, P., Smalla, K., Wellington, E.M., 1997. Analysis of actinomycete communities by specific amplification of genes encoding 16S rRNA and gel-electrophoretic separation in denaturing gradients. Appl. Environ. Microbiol. 63, 3233-3241.

Hopkin S.P., 2007. A key to the collembola (springtails) of Britain and Ireland. FSC publications.

Hothorn, T., Zeileis, A., Farebrother, R.W., Cummins, C., Millo, G., Mitchell, D., 2015. 1mtest: Testing linear regression models. R Packag. version 0.9-34.

Huot, H., 2013. Formation, fonctionnement et évolution d'un Technosol sur des boues sidérurgiques. Doctoral dissertation, University of Lorraine.

Huot, H., Simonnot, M.-O., Marion, P., Yvon, J., Donato, P., Morel, J.-L., 2011. Characteristics and potential pedogenetic processes of a Technosol developing on iron industry deposits. J. Soils Sediments 13, 555-568.

Ingram, L.J., Schuman, G.E., Stahl, P.D., Spackman, L.K., 2005. Microbial Respiration and Organic Carbon Indicate Nutrient Cycling Recovery in Reclaimed Soils. Soil Sci. Soc. Am. J. 69, 1737.

IUSS Working Group WRB, 2014. World reference base for soil resources 2014. International soil classification system for naming soils and creating legends for soil maps, World Soil Resources Reports No. 106.

Joimel, S., 2015. Biodiversité et caractéristiques physico-chimiques des sols de jardins associatifs urbains français. Doctoral dissertation, University of Lorraine.

Joimel, S., Cortet, J., Jolivet, C.C., Saby, N.P.A., Chenot, E.D., Branchu, P., Consalès, J.N., Lefort, C., Morel, J.L., Schwartz, C., 2016. Physico-chemical characteristics of topsoil for contrasted forest, agricultural, urban and industrial land uses in France. Sci. Total Environ. 545-546, 40-47.

Joimel, S., Schwartz, C., Hedde, M., Kiyota, S., Krogh, P.H., Nahmani, J., Pérès, G., Vergnes, A., Cortet, J., 2017. Urban and industrial land uses have a higher soil biological quality than expected from physicochemical quality. Sci. Total Environ. 584-585, 614-621.

Kandeler, E., Tscherko, D., Bruce, K.D., Stemmer, M., Hobbs, P.J., Bardgett, R.D., Amelung, W., 
2000. Structure and function of the soil microbial community in microhabitats of a heavy metal polluted soil. Biol. Fert. Soils. 32, 390-400.

Karlen, D.L., Ditzler, C.A., Andrews, S.S., 2003. Soil quality: Why and how? Geoderma 114, 145156.

Keesstra, S.D., Bouma, J., Wallinga, J., Tittonell, P., Smith, P., Cerdà, A., Montanarella, L., Quinton, J.N., Pachepsky, Y., van der Putten, W.H., Bardgett, R.D., Moolenaar, S., Mol, G., Jansen, B., Fresco, L.O., 2016. The significance of soils and soil science towards realization of the United Nations Sustainable Development Goals. Soil 2, 111-128.

Khan, A.G., Kuek, C., Chaudhry, T.M., Khoo, C.S., Hayes, W.J., 2000. Role of plants, mycorrhizae and phytochelators in heavy metal contaminated land remediation. Chemosphere 41, 197-207.

Koske, R.E., Gemma, J.N., 1989. A modified procedure for staining roots to detect VA mycorrhizas. Mycol. Res. 92, 486-488.

Kuznetsova, N.A., 2003. New approaches to the assessment of structural organization of communities in springtails (hexapoda: Collembola). Russ. J. Ecol. 34, 248-254.

Laliberté, E., Legendre, P., Shipley, B., Laliberté, M., 2014. FD: measuring functional diversity from multiple traits, and other tools for functional ecology. R Packag. version 1.0-12.

Lavelle, P., Decaëns, T., Aubert, M., Barot, S., Blouin, M., Bureau, F., Margerie, P., Mora, P., Rossi, J.-P., 2006. Soil invertebrates and ecosystem services. Eur. J. Soil Biol. 42, 3-15.

Levin, M., Kim, K., Morel, J., Burghardt, W., 2017. Soils within Cities. Global approaches to their sustainable management. GeoEcology Essays.

Leys, N.M., Ryngaert, A., Bastiaens, L., Wattiau, P., Top, E.M., Verstraete, W., Springael, D., 2005. Occurrence and community composition of fast-growing Mycobacterium in soils contaminated with polycyclic aromatic hydrocarbons. FEMS Microbiol. Ecol. 51, 375-388.

Leyval, C., Joner, E.J., 2001. Bioavailability of heavy metals in the mycorrhizosphere, in: Gobran, G.R., Lombi, E., Walter, W. (Eds.), Trace Elements in the Rhizosphere. CRC Press, pp. 165185.

Li, Y.T., Rouland, C., Benedetti, M., Li, F. bai, Pando, A., Lavelle, P., Dai, J., 2009. Microbial biomass, enzyme and mineralization activity in relation to soil organic $\mathrm{C}, \mathrm{N}$ and $\mathrm{P}$ turnover influenced by acid metal stress. Soil Biol. Biochem. 41, 969-977.

Lord, R.A., 2015. Reed canarygrass (Phalaris arundinacea) outperforms Miscanthus or willow on marginal soils, brownfield and non-agricultural sites for local, sustainable energy crop production. Biomass and Bioenergy 78, 110-125.

Lord, R., Atkinson, J., Lane, A., Scurlock, J., Street, G., 2008. Biomass, Remediation, re-Generation (BioReGen Life Project): Reusing brownfield sites for renewable energy crops. ASCE Geotech. Spec. Publ. 177, 527-534.

Lucas-Borja, M.E., Hedo, J., Cerdá, A., Candel-Pérez, D., Viñegla, B., 2016. Unravelling the importance of forest age stand and forest structure driving microbiological soil properties, enzymatic activities and soil nutrients content in Mediterranean Spanish black pine(Pinus nigra Ar. ssp. salzmannii) Forest. Sci. Total Environ. 562, 145-154.

Lucisine, P., Lecerf, A., Danger, M., Felten, V., Aran, D., Auclerc, A., Gross, E.M., Huot, H., Morel, J.-L., Muller, S., Nahmani, J., Maunoury-Danger, F., 2015. Litter chemistry prevails over litter consumers in mediating effects of past steel industry activities on leaf litter decomposition. Sci. Total Environ. 537, 213-224.

Lueders, T., Wagner, B., Claus, P., Friedrich, M., 2004. Stable isotope probing of rDNA and DNA reveals a dynamic methylotroph community and interactions with fungi and protozoa in oxic rice field soil. Environ. Microbiol. 6, 60-72.

Macfadyen, A., 1961. Improved funnel-type extractors for soil arthropods. J. Anim. Ecol. 30, 171184.

Mao, Y., Sang, S., Liu, S., Jia, J., 2014. Spatial distribution of $\mathrm{pH}$ and organic matter in urban soils and its implications on site-specific land uses in Xuzhou, China. C. R. Biol. 337, 332-337.

Marx, M.-C., Wood, M., Jarvis, S.C., 2001. A microplate fluorimetric assay for the study of enzyme diversity in soils. Soil Biol. Biochem. 33, 1633-1640.

Meier, S., Borie, F., Bolan, N., Cornejo, P., Meier, S.A., 2012. Phytoremediation of Metal-Polluted Soils by Arbuscular Mycorrhizal Fungi. Environ. Sci. Technol. 7, 741-775.

Miransari, M., 2010. Contribution of arbuscular mycorrhizal symbiosis to plant growth under different 
types of soil stress. Plant Biol. (Stuttg). 12, 563-9.

Mol, G., Keesstra, S., 2012. Soil science in a changing world. Curr. Opin. Environ. Sustain. 4, 473477.

Morel, J.L., Schwartz, C., Florentin, L., de Kimpe, C., 2005. Urban soils - Ed: Hillel, Daniel, in: Encyclopedia of Soils in the Environment. Elsevier, Oxford, pp. 202-208.

Morriën, E., Hannula, S.E., Snoek, L.B., Helmsing, N.R., Zweers, H., Hollander, M. De, Soto, R.L., Bouffaud, M.L., Buée, M., Dimmers, W., Duyts, H., Geisen, S., Girlanda, M., Jørgensen, H.-B., Jensen, J., Plassart, P., Redecker, D., Schmelz, R.M., Schmidt, O., Thomson, B.C., Tisserant, E., Uroz, S., Winding, A., Bailey, M.J., Bonkowski, M., Faber, J.H., Martin, F., Lemanceau, P., Boer, W. De, Veen, J.A. van, Putten, W.H. van der, 2016. Soil networks become more connected and take up more carbon as nature restoration progresses. Nat. Commun. 8, 14349.

Mulligan, C.N., Yong, R.N., 2004. Natural attenuation of contaminated soils. Environ. Int. 30, $587-$ 601.

Muñoz-Rojas, M., Erickson, T.E., Martini, D., Dixon, K.W., Merritt, D.J., 2016. Soil physicochemical and microbiological indicators of short, medium and long term post-fire recovery in semi-arid ecosystems. Ecol. Indic. 63, 14-22.

Muscolo, A., Panuccio, M.R., Mallamaci, C., Sidari, M., 2014. Biological indicators to assess shortterm soil quality changes in forest ecosystems. Ecol. Indic. 45, 416-423.

Nahmani, J., Capowiez, Y., Lavelle, P., 2005. Effects of metal pollution on soil macroinvertebrate burrow systems. Biol. Fertil. Soils 42, 31-39.

Nahmani, J., Lavelle, P., 2002. Effects of heavy metal pollution on soil macrofauna in a grassland of Northern France. Eur. J. Soil Biol. 38, 297-300.

Nahmani, J., Rossi, J.P., 2003. Soil macroinvertebrates as indicators of pollution by heavy metals. C. R. Biol. 326, 295-303.

Norris, M.D., Avis, P.G., Reich, P.B., Hobbie, S.E., 2013. Positive feedbacks between decomposition and soil nitrogen availability along fertility gradients. Plant Soil 367, 347-361.

Ouvrard, S., Barnier, C., Bauda, P., Beguiristain, T., Biache, C., Bonnard, M., Caupert, C., Cébron, A., Cortet, J., Cotelle, S., Dazy, M., Faure, P., Masfaraud, J.F., Nahmani, J., Palais, F., Poupin, P., Raoult, N., Vasseur, P., Morel, J.L., Leyval, C., 2011. In situ assessment of phytotechnologies for multicontaminated soil management. Int. J. Phytoremediation 13, 245-263.

Ouvrard, S., Chenot, E.D., Masfaraud, J.F., Schwartz, C., 2013. Long-term assessment of natural attenuation: Statistical approach on soils with aged PAH contamination. Biodegradation 24, 539548.

Pavan Fernandes, S.A., Bettiol, W., Cerri, C.C., 2005. Effect of sewage sludge on microbial biomass, basal respiration, metabolic quotient and soil enzymatic activity. Appl. Soil Ecol. 30, 65-77.

Peng, R.-H., Xiong, A.-S., Xue, Y., Fu, X.-Y., Gao, F., Zhao, W., Tian, Y.-S., Yao, Q.-H., 2008. Microbial biodegradation of polyaromatic hydrocarbons. FEMS Microbiol. Rev. 32, 927-955.

Pey, B., Laporte, M.A., Nahmani, J., Auclerc, A., Capowiez, Y., Caro, G., Cluzeau, D., Cortet, J., Decaens, T., Dubs, F., Joimel, S., Guernion, M., Briard, C., Grumiaux, F., Laporte, B., Pasquet, A., Pelosi, C., Pernin, C., Ponge, J.F., Salmon, S., Santorufo, L., Hedde, M., 2014. A thesaurus for soil invertebrate trait-based approaches. PLoS One 9, e108985.

Pižl, V., Schlaghamerský, J., Jan, T., 2009. The effects of polycyclic aromatic hydrocarbons and heavy metals on terrestrial annelids in urban soils. Pesqui. Agropecuária Bras. 44, 1050-1055.

Ponge, J.-F., Pérès, G., Guernion, M., Ruiz-Camacho, N., Cortet, J., Pernin, C., Villenave, C., Chaussod, R., Martin-Laurent, F., Bispo, A., Cluzeau, D., 2013. The impact of agricultural practices on soil biota: A regional study. Soil Biol. Biochem. 67, 271-284.

Ponge, J.F., Gillet, S., Dubs, F., Fedoroff, E., Haese, L., Sousa, J.P., Lavelle, P., 2003. Collembolan communities as bioindicators of land use intensification. Soil Biol. Biochem. 35, 813-826.

Rachwal, M., Magiera, T., Wawer, M., 2015. Coke industry and steel metallurgy as the source of soil contamination by technogenic magnetic particles, heavy metals and polycyclic aromatic hydrocarbons. Chemosphere 138, 863-873.

Rawls, W.J., Pachepsky, Y.A., Ritchie, J.C., Sobecki, T.M., Bloodworth, H., 2003. Effect of soil organic carbon on soil water retention. Geoderma 116, 61-76.

Rizvi, S.H., Gauquelin, T., Gers, C., Guérold, F., Pagnout, C., Baldy, V., 2012. Calcium-magnesium liming of acidified forested catchments: Effects on humus morphology and functioning. Appl. 
Soil Ecol. 62, 81-87.

Roberts, J., Mason, N., Smith, M., 2006. Tree roots in the built environment. The Stationery Office.

Robinson, S.L., Lundholm, J.T., 2012. Ecosystem services provided by urban spontaneous vegetation. Urban Ecosyst. 15, 545-557.

Rodrigues, F., Carvalho, M.T., Evangelista, L., De Brito, J., 2013. Physical-chemical and mineralogical characterization of fine aggregates from construction and demolition waste recycling plants. J. Clean. Prod. 52, 438-445.

Rokia, S., Séré, G., Schwartz, C., Deeb, M., Fournier, F., Nehls, T., Damas, O., Vidal-Beaudet, L., 2014. Modelling agronomic properties of Technosols constructed with urban wastes. Waste Manag. 34, 2155-2162.

Ruiz, N., Mathieu, J., Célini, L., Rollard, C., Hommay, G., Iorio, E., Lavelle, P., 2011. IBQS: A synthetic index of soil quality based on soil macro-invertebrate communities. Soil Biol. Biochem. 43, 2032-2045.

Sabais, A.C.W., Scheu, S., Eisenhauer, N., 2011. Plant species richness drives the density and diversity of Collembola in temperate grassland. Acta Oecologica 37, 195-202.

Sæbo, A., Persson, T., Hanslin, H.M., Höglind, M., 2017. Intensify production , transform biomass to energy and novel goods and protect soils in Europe. Facce Surplus. 1-66.

Santorufo, L., Cortet, J., Arena, C., Goudon, R., Rakoto, A., Morel, J.L., Maisto, G., 2014. An assessment of the influence of the urban environment on collembolan communities in soils using taxonomy- and trait-based approaches. Appl. Soil Ecol. 78, 48-56.

Santorufo, L., Van Gestel, C.A.M., Rocco, A., Maisto, G., 2012. Soil invertebrates as bioindicators of urban soil quality. Environ. Pollut. 161, 57-63.

Schloter, M., Dilly, O., Munch, J.C., 2003. Indicators for evaluating soil quality. Agric. Ecosyst. Environ. 98, 255-262.

Séré, G., 2007. Fonctionnement et évolution pédogénétiques de Technosols issus d'un procédé de construction de sol. Doctoral dissertation, University of Lorraine.

Séré, G., Schwartz, C., Ouvrard, S., Sauvage, C., Renat, J.C., Morel, J.L., 2008. Soil construction: A step for ecological reclamation of derelict lands. J. Soils Sediments 8, 130-136.

Singh, B.K., Quince, C., Macdonald, C.A., Khachane, A., Thomas, N., Al-Soud, W.A., Sørensen, S.J., He, Z., White, D., Sinclair, A., Crooks, B., Zhou, J., Campbell, C.D., 2014. Loss of microbial diversity in soils is coincident with reductions in some specialized functions. Environ. Microbiol. $16,2408-2420$.

Sinsabaugh, R.L., Reynolds, H., Long, T.M., 2000. Rapid assay for amidohydrolase (urease) activity in environmental samples. Soil Biol. Biochem. 32, 2095-2097.

Small, E., Sadler, J.P., Telfer, M., 2006. Do landscape factors affect brownfield carabid assemblages? Sci. Total Environ. 360, 205-222.

Small, E.C., Sadler, J.P., Telfer, M.G., 2002. Carabid beetle assemblages on urban derelict sites in Birmingham, UK. J. Insect Conserv. 6, 233-246.

Smith, S.E., Read, D.J., 2008. Mycorrhizal symbiosis. Third Edition. Academic press.

Stauffer, M., Leyval, C., Brun, J.-J., Leportier, P., Berthelin, J., 2014. Effect of willow short rotation coppice on soil properties after three years of growth as compared to forest, grassland and arable land uses. Plant Soil 377, 423-438.

Thavamani, P., Malik, S., Beer, M., Megharaj, M., Naidu, R., 2012. Microbial activity and diversity in long-term mixed contaminated soils with respect to polyaromatic hydrocarbons and heavy metals. J. Environ. Manage. 99, 10-17.

Thion, C., Cébron, A., Beguiristain, T., Leyval, C., 2012. Long-term in situ dynamics of the fungal communities in a multi-contaminated soil are mainly driven by plants. FEMS Microbiol. Ecol. $82,169-181$.

Torsvik, V., R, S., Goksoyr, J., 1996. Total bacterial diversity in soil and sediment communities - a review. J Ind. Microb 17, 170-178.

Torsvik, V., Sørheim, L., 2002. Microbial diversity and function in soil: from genes to ecosystems. Curr. Opin. Microbiol. 5, 240-245.

Trouvelot, A., Kough, J., Gianinazzi-Pearson, V., 1986. Evaluation of VA infection levels in root systems - Research for estimation methods having a functional significance. in: Physiological and Genetical Aspects of Mycorrhizae. INRA-Press, pp. 217-221. 
Uyttebroek, M., Breugelmans, P., Janssen, M., Wattiau, P., Joffe, B., Karlson, U., Ortega-Calvo, J.J., Bastiaens, L., Ryngaert, A., Hausner, M., Springael, D., 2006. Distribution of the Mycobacterium community and polycyclic aromatic hydrocarbons (PAHs) among different size fractions of a long-term PAH-contaminated soil. Environ. Microbiol. 8, 836-847.

Vainio, E.J., Hantula, J., 2000. Direct analysis of wood-inhabiting fungi using denaturing gradient gel electrophoresis of amplified ribosomal DNA. Mycol. Res. 104, 927-936.

Van Der Heijden, M.G., Bardgett, R.D., Van Straalen, N.M., 2008. The unseen majority: soil microbes as drivers of plant diversity and productivity in terrestrial ecosystems. Ecol. Lett. 11, 296-310.

Varallyay, G., 2000. Soil quality in relation to the concepts of multifunctionality and sustainable development. Soil Qual. Sustain. Agric. Environ. Secur. Cent. East. Eur. 69, 17-33.

Vidal Legaz, B., Maia De Souza, D., Teixeira, R.F.M., Antón, A., Putman, B., Sala, S., 2016. Soil quality, properties, and functions in Life Cycle Assessment: an evaluation of models. J. Clean. Prod. 140, 1-14.

Vinhal-Freitas, I.C., Corrêa, G.F., Wendling, B., Bobul'ská, L., Ferreira, A.S., 2017. Soil textural class plays a major role in evaluating the effects of land use on soil quality indicators. Ecol. Indic. 74, $182-190$.

Vogel-Mikuš, K., Drobne, D., Regvar, M., 2005. Zn, Cd and Pb accumulation and arbuscular mycorrhizal colonisation of pennycress Thlaspi praecox Wulf. (Brassicaceae) from the vicinity of a lead mine and smelter in Slovenia. Environ. Pollut. 133, 233-242.

Wagg, C., Bender, S.F., Widmer, F., Heijden, M.G.A. van der, 2014. Soil biodiversity and soil community composition determine ecosystem multifunctionality. Proc. Natl. Acad. Sci. U. S. A. $111,5266-70$.

Walmsley, A., Cerdà, A., 2017. Soil macrofauna and organic matter in irrigated orchards under Mediterranean climate. Biol. Agric. Hortic. 8765, 1-11.

Wardle, D.A., 2006. The influence of biotic interactions on soil biodiversity. Ecol Lett 9, 870-86.

Wardle, D.A., Bardgett, R.D., Klironomos, J.N., Setälä, H., Van Der Putten, W.H., Wall, D.H., 2004. Ecological linkages between aboveground and belowground biota. Science. 304, 1629-1633.

Wilschut, M., Theuws, P.A.W., Duchhart, I., 2013. Phytoremediative urban design: Transforming a derelict and polluted harbour area into a green and productive neighbourhood. Environ. Pollut. $183,81-88$.

Wisz, M.S., Pottier, J., Kissling, W.D., Pellissier, L., Lenoir, J., Damgaard, C.F., Dormann, C.F., Forchhammer, M.C., Grytnes, J.A., Guisan, A., Heikkinen, R.K., Høye, T.T., Kühn, I., Luoto, M., Maiorano, L., Nilsson, M.C., Normand, S., Öckinger, E., Schmidt, N.M., Termansen, M., Timmermann, A., Wardle, D.A., Aastrup, P., Svenning, J.C., 2013. The role of biotic interactions in shaping distributions and realised assemblages of species: Implications for species distribution modelling. Biol. Rev. 88, 15-30.

Wong, M., Bradshaw, A., 2002. The restoration and management of derelict land: modern approaches. World Scientific.

Yang, Y., Campbell, C.D., Clark, L., Cameron, C.M., Paterson, E., 2006. Microbial indicators of heavy metal contamination in urban and rural soils. Chemosphere 63, 1942-1952. 


\section{Figure legends:}

Figure 1: Localization of the sites where the six derelict soils were sampled. A:Biotechnosol (in Homécourt); B:Retonfey; C:Homécourt; D:Moyeuvre-Petite; E:Micheville; F:Jeandelaincourt.

Figure 2: Scheme of the different sampling quadrats: $1 \times 1 \mathrm{~m}$ quadrats for herbaceous plant diversity $\left(\mathrm{n}^{\circ} 1\right) ; 0.5 \times 0.5 \mathrm{~m}$ quadrats for plant shoot biomass $\left(\mathrm{n}^{\circ} 2\right) ; 0.1 \times 0.1 \mathrm{~m}$ quadrats for the mesofauna $\left(\mathrm{n}^{\circ} 3\right)$ and physicochemical and microbiological analyses $\left(\mathrm{n}^{\circ} 4\right) ; 0.25 \times 0.25 \mathrm{~m}$ for the macrofauna $\left(\mathrm{n}^{\circ} 5\right)$. Five or four replicates were sampled per site.

Figure 3: Co-inertia analysis of abiotic and biotic parameters of the six derelict soil samples. Red squares and green circles represent the PCA sample map according to abiotic and biotic variables, respectively. The biggest squares and circles are barycenters. A, B, C, D, E and F are the soil names. $\mathrm{PAH}=$ sum of the $16 \mathrm{PAH}$ concentrations; $\mathrm{Clay}=\%$ of clay; $\mathrm{P}=$ available phosphorous (Olsen method); $\mathrm{OM}=$ Organic Matter; $\mathrm{WHC}=$ Water Holding Capacity; $\mathrm{CEC}=$ Cation Exchange Capacity; $\mathrm{C}: \mathrm{N}=$ carbon/nitrogen ratio; [Exchangeable cations by cobaltihexamine] $\mathrm{Ca}=$ calcium; $\mathrm{Na}=$ sodium; $\mathrm{K}=$ potassium; $\mathrm{Mg}=$ =magnesium. [Elements] $\mathrm{Pb}=$ lead; $\mathrm{Zn}=\mathrm{zinc} ; \mathrm{Cd}=$ cadmium; Age=from the date of the last anthropogenic action. $\mathrm{R}_{-}=$richness (Collembola=species richness; Plant=genus or family richness; Macrofauna=family richness; Fungi and bacteria=number of ribotypes); Plant=plant biomass; Collembola and Macrofauna $=$ density; Fungi and Bacteria=rDNA gene copy density; Mycorrhizae=mycorrhizal colonization frequency.

Figure 4: Co-inertia analysis of abiotic and functional parameters of the six derelict soils ( 29 samples). Red squares and blue circles represent the PCA sample map according to abiotic and functional variables, respectively. The biggest squares and circles are barycenters. A, B, C, D, E and F are the soil names. $\mathrm{PAH}=$ sum of the $16 \mathrm{PAH}$ concentrations; $\mathrm{Clay}=\%$ of clay; $\mathrm{P}=$ available phosphorous (Olsen method); OM=Organic Matter; WHC=Water Holding Capacity; $\mathrm{CEC}=$ Cation Exchange Capacity; $\mathrm{C}: \mathrm{N}=$ carbon/nitrogen ratio; [Exchangeable cations by cobaltihexamine] $\mathrm{Ca}=$ calcium; $\mathrm{Na}=$ sodium; $\mathrm{K}=$ potassium; $\mathrm{Mg}=$ magnesium. [Elements] $\mathrm{Pb}=$ lead; $\mathrm{Zn}=$ zinc; $\mathrm{Cd}=$ cadmium; Age=from the date of the last anthropogenic action. Macro-decomposer=community-weighted mean of decomposers in the macrofauna. Meso-decomposer=community-weighted mean of decomposers in the mesofauna. Urease=urease activity; Phosphatase=phosphatase activity; FDA=FDA hydrolysis activity; $\mathrm{AMC}=$ Average Mineralization Capacity; GP_PAH=relative density of the PAH-dioxygenase gene in Gram-positive bacteria; GN_PAH= relative density of the PAH-dioxygenase gene in Gram-negative bacteria. 


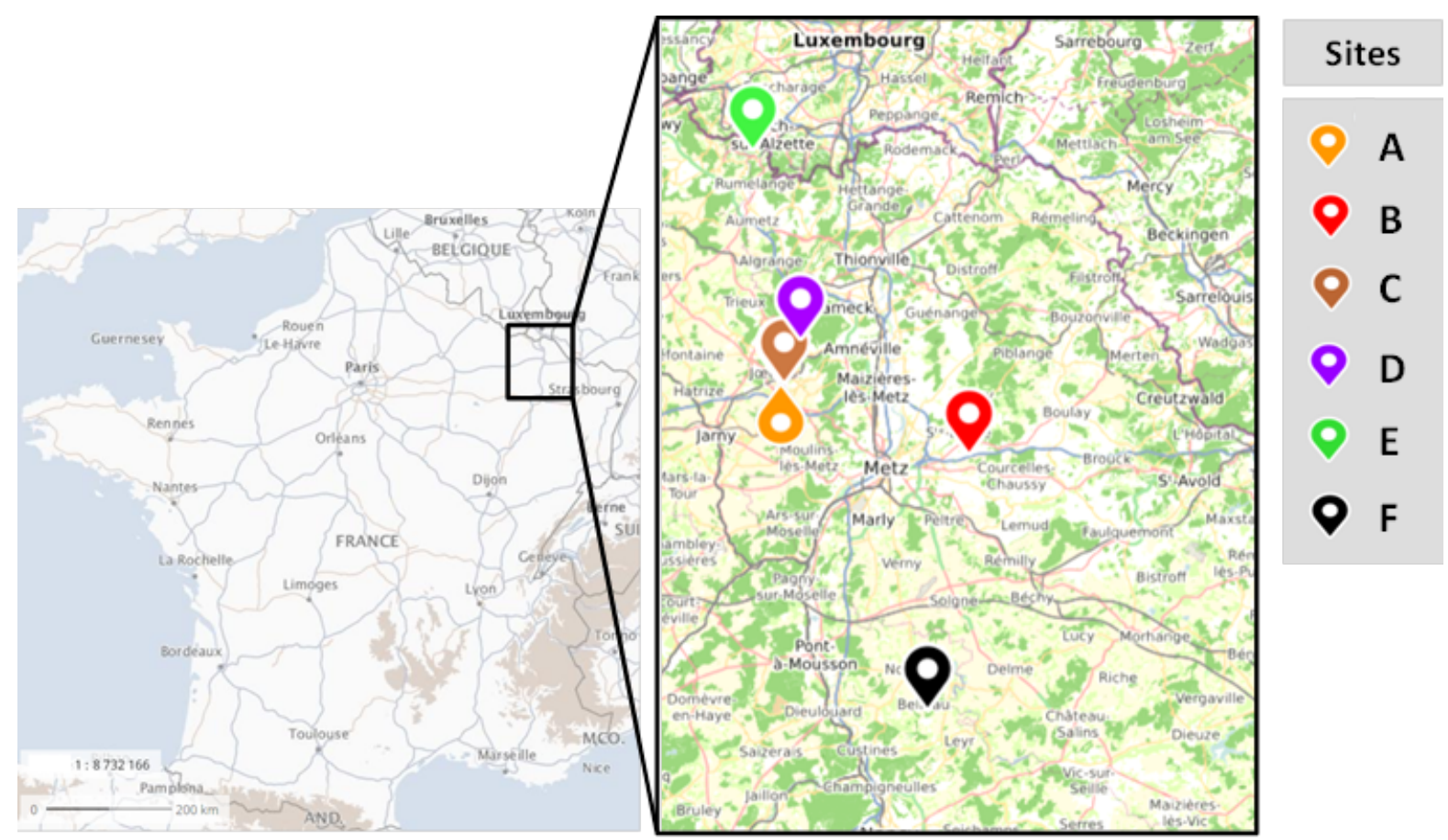

Fig. 1

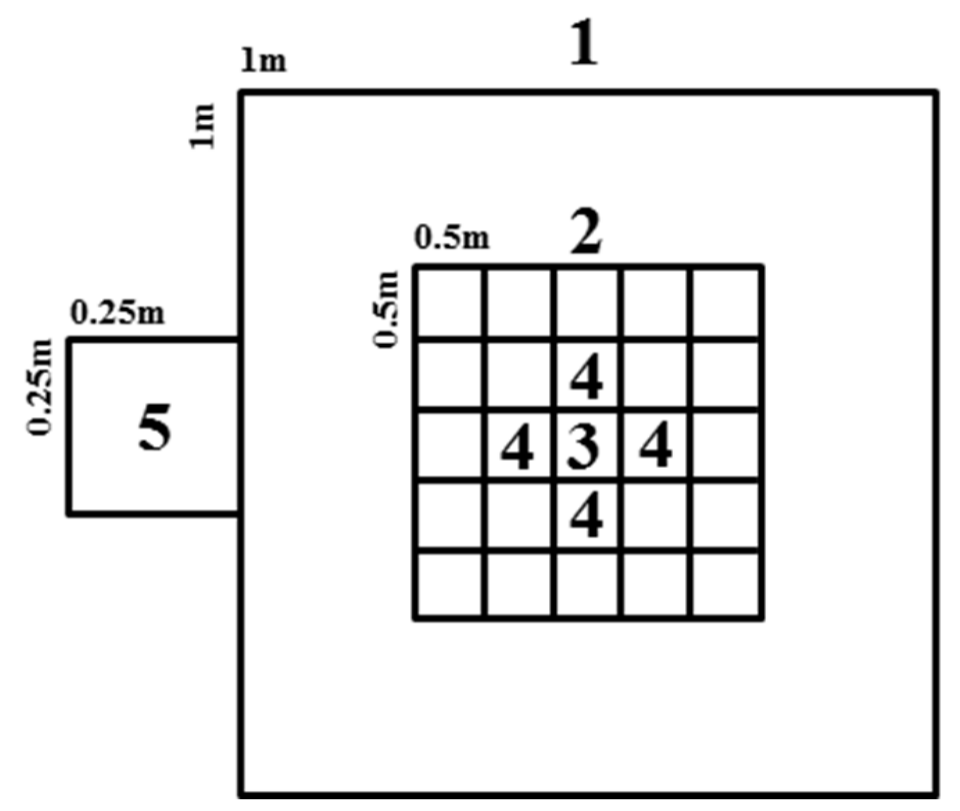

1 Herbaceous diversity

2 Plant shoot biomass

3 Mesofauna 4 Physico-chemistry
and microbiology

5 Macrofauna

Fig. 2 
ABIOTIC PARAMETERS
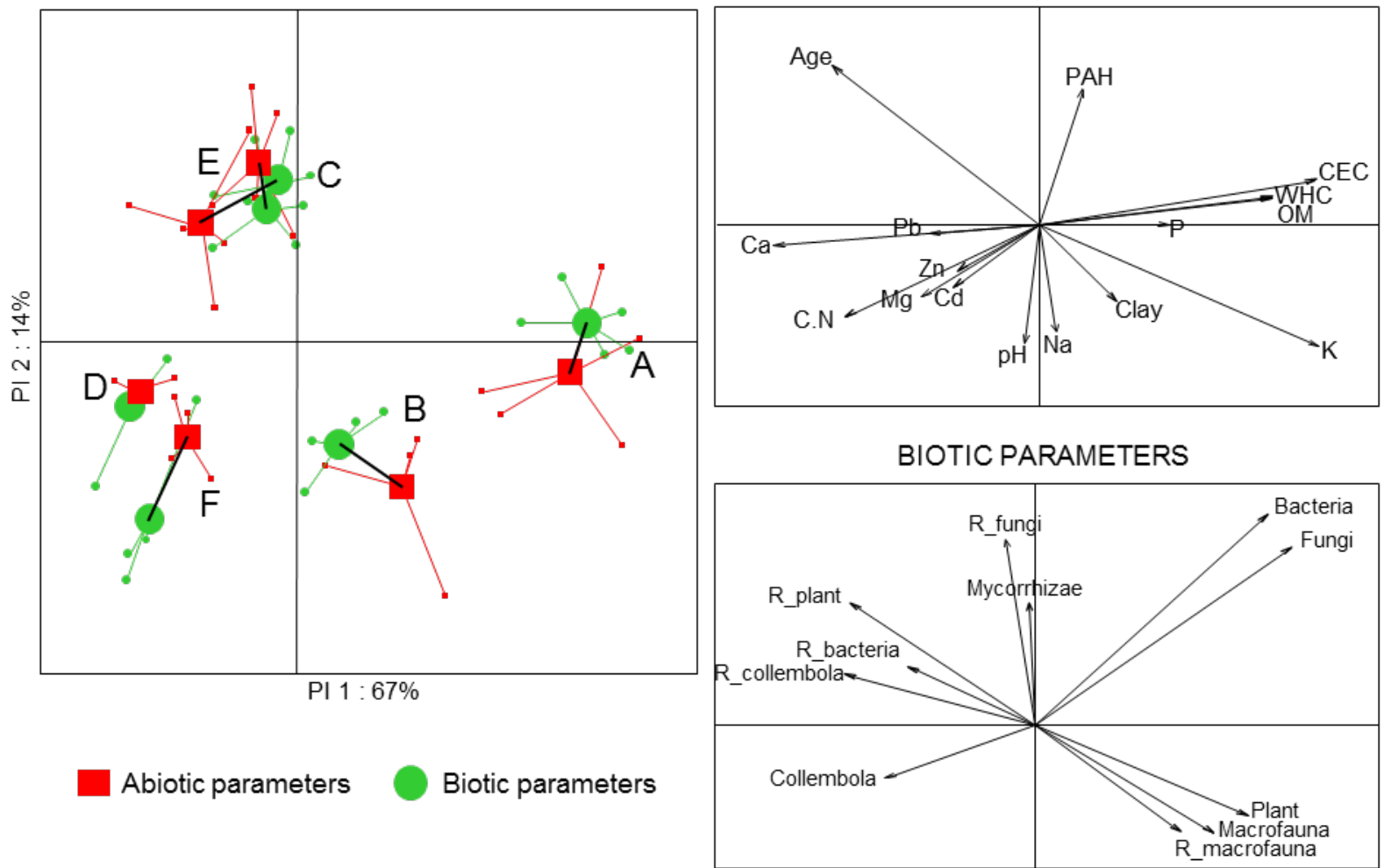

Fig. 3 


\section{ABIOTIC PARAMETERS}
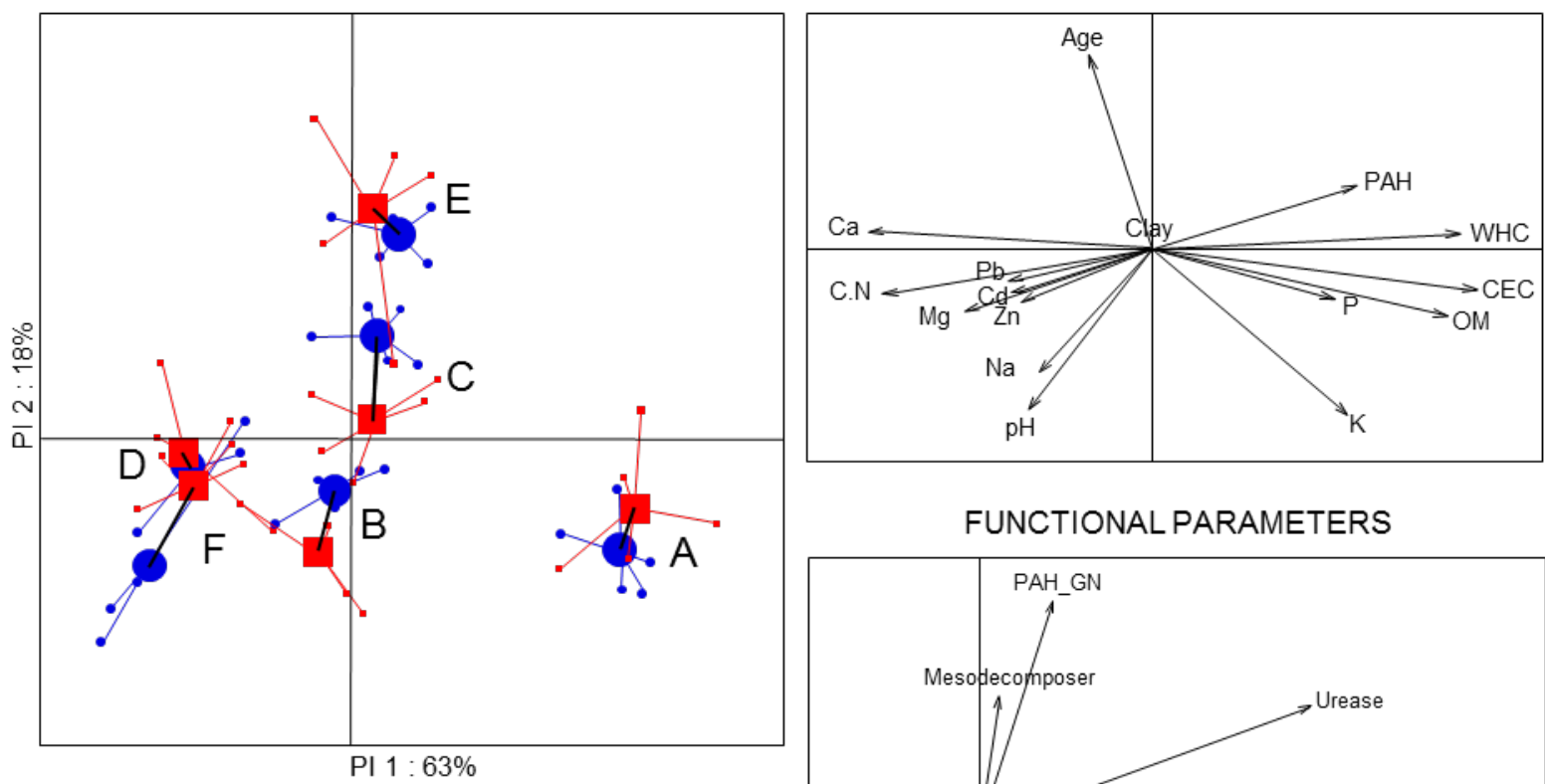

Abiotic parameters

Functional parameters

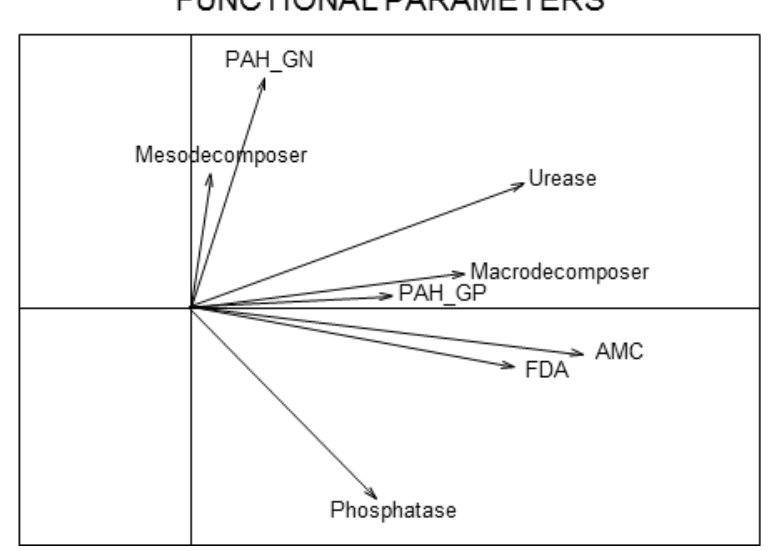

Fig. 4 